Tiffany I. Leung, MD, MPH, FACP, FAMIA ${ }^{1 *}$, Rebecca Snyder, MSIS², Sima S. Pendharkar, MD, MPH, FACPł, Chwen-Yuen Angie Chen, MD, FACP, FASAM ${ }^{4 \ddagger}$

\title{
Physician Suicide: A Scoping Literature Review to Highlight Opportunities for Prevention
}

\author{
'Faculty of Health, Medicine, and Life Sciences, Department of Internal Medicine, Maastricht University, Maastricht, The Netherlands \\ 2Library Services, University of Texas Southwestern Medical Center, Dallas, TX, USA \\ ${ }^{3}$ Division of Hospital Medicine, The Brooklyn Hospital Center, Icahn School of Medicine Mt. Sinai, Brooklyn, NY, USA \\ ${ }^{4}$ Department of Primary Care and Population Health, Stanford University, Palo Alto, CA, USA \\ *email: t.leunglamaastrichtuniversity.nl \\ \#Indicates equal contributions as last authors to the production of this manuscript.
}

DOI: 10.2478/gp-2020-0014

Received: 27 February 2020; Accepted: 12 May 2020

\begin{abstract}
Objective: The aim of this scoping review is to map the current landscape of published research and perspectives on physician suicide. Findings could serve as a roadmap for further investigations and potentially inform efforts to prevent physician suicide.

Methods: Ovid MEDLINE, PsycINFO, and Scopus were searched for English-language publications from August 21, 2017 through April 28, 2018. Inclusion criteria were a primary outcome or thesis focused on suicide (including suicide completion, attempts, and thoughts or ideation) among medical students, postgraduate trainees, or attending physicians. Opinion articles were included. Studies that were non-English or those that only mentioned physician burnout, mental health, or substance use disorders were excluded. Data extraction was performed by two authors.

Results: The search yielded 1,596 articles, of which 347 articles passed to the full-text review round. The oldest article was an editorial from 1903; 210 (60.3\%) articles have been published from 2000 to present. Authors originated from 37 countries, and 143 (41.2\%) were opinion articles. The most discussed were suicide risk factors and culture of practice issues, while the least discussed themes included public health and postvention.

Conclusions: Consistency and reliability of data and information about physician suicides could be improved. Data limitations partly contribute to these issues. Also, various suicide risk factors for physicians have been explored, and several remain poorly understood. Based on this scoping review, a public health approach, including surveillance and early warning systems, investigations of sentinel cases, and postvention may be impactful next steps in preventing physician deaths by suicide.
\end{abstract}

\section{Keywords}

Physician suicide, Burnout, professional, Job satisfaction, Physicians, Suicide, Parasuicide, Healthcare workforce, Occupational health, Workplace suicide

\section{INTRODUCTION}

Physician suicide is concerning for the medical community and general public and remains poorly understood. Several medical organizations have begun launching various initiatives to address physician well-being; yet, efforts to address physician suicide remain specific to the organization or institution. To identify important knowledge and implementation gaps toward physician suicide prevention, this scoping literature review aims to map the landscape of published research and perspectives on physician suicide. Specifically, the aim is to describe research on physician suicidal behaviors among medical students, postgraduate trainees, including residents and fellows, and physicians. Findings could serve as a roadmap for informing further study, evidence-based policy, and interventions to prevent physician suicide. 


\section{METHODS}

\section{Search Strategy}

This scoping review was conducted following the Arksey and O'Malley framework as expanded upon and outlined within the Joanna Briggs Institute Reviewers' Manual (Arksey and O'Malley 2005; Peters et al. 2015). A scoping review, in contrast to other review types, can map evidence in an emerging research area, and thereby identify the conceptual boundaries of a topic, clarifying gaps and key concepts and reporting on existing types of evidence that address the topic (The Joanna Briggs Institute 2015). This differs from a systematic review, which gathers and assesses the quality of quantitative evidence to report on the effectiveness of a particular intervention in achieving a certain outcome (The Joanna Briggs Institute 2015).

The research question was broadly designed to gather and analyze articles that mention physician suicide. No date range for the search was specified. The initial searches were performed on August 21, 2017 in Ovid MEDLINE and on October 11, 2017 in Ovid PsycINFO. Authors contributed seed articles that they had previously identified as relevant to physician suicide (Hem et al. 2000; Aasland, Ekeberg, and Schweder 2001; Tyssen et al. 2004; Hawton, Malmberg, and Simkin 2004; Gold, Sen, and Schwenk 2013), which were analyzed by the medical librarian co-author. Search terms and databases were then selected and tested based on this analysis. The search strategy also underwent a peer review process with two additional medical librarians. An updated search was run again on April 28, 2018 in Ovid MEDLINE, PsycINFO, and Scopus. Detailed search terms are available in Appendix 1.

\section{Eligibility Criteria}

Inclusion criteria were English-language papers with a primary outcome, measure, or thesis focused on death by suicide or suicidal behaviors among physicians, including suicide attempts, and suicidal thoughts and ideation. Physicians included medical students, postgraduate trainees (residents and fellows), and physicians at any career stage. Opinion articles were also included if they otherwise met the inclusion criteria. These included perspectives, letters to the editor or their replies, essays, and viewpoints with a focus specifically on physician suicide. Exclusion criteria were non-English publications and those only pertaining to physician burnout, mental health, substance use disorders, or other media, such as newspaper, magazine, or other journalistic articles. Query results totaled 1,596 articles after deduplication. Two authors reviewed abstracts and titles for inclusion in the full-text review round and disagreements were adjudicated by a third author. Next, during the full-text review round, two authors again reviewed the full-text articles for inclusion with a third author adjudicating disagreements. Covidence, a literature review management software, was used to review articles during inclusion and exclusion steps.

\section{Data Extraction and Analysis}

Two authors (TL, SP) performed data extraction using a data charting table. Data extracted included: primary thesis or outcome measure (e.g. death by suicide, suicide attempt, suicidal ideation or thoughts), date of publication, authors' country affiliation, type of publication, study design, country of participants, tools used to ascertain outcome measures, and physician population (specialties, career stage). While reviewing articles, authors used an open coding approach to tag articles by key topics or themes (e.g. suicidal ideation, depression, prevention, substance use, etc.). The aim was to inductively identify key themes across the published literature included in this scoping review. During each subsequent round of review, tags could be added to articles. After all articles were reviewed and tagged by two authors (TL, SP, CYAC), one of the authors (TL) re-reviewed all articles to add tags until a point of saturation was reached and no further topic tags could be added. Tags were then condensed into a core set of themes. These themes were assembled into a framework based on their frequency of occurrence, resulting in a map of the most published themes about physician suicide. Findings are summarized in narrative form.

\section{RESULTS}

The 347 articles that met the inclusion criteria (Figure 1) covered a broad range of publication types over time and from countries worldwide. The earliest publications were editorials (Table 1), with the first published in 1903 by an unknown author. Overall, 143 (41.2\%) opinion articles were published, suggesting an ongoing public dialog about physician suicide in academic journals lasting over a century. Of the remaining 204 (58.8\%) articles, cross-sectional study design involving a survey was the most common study design. Of these, 13 described interventions intended to prevent physician suicide. Such articles frequently introduced the paper by describing "a tragic case," when the death of one or more physicians by suicide stimulates the development or implementation of an intervention (Shanafelt et al. 2019).

Authors from 37 countries published English-language articles on physician suicidal behaviors, including the United States, 
Table 1. Article characteristics from scoping review of literature on physician suicide, 1903-2018

\begin{tabular}{|c|c|c|}
\hline Publication date range & No. $(\%)$ of non-opinion articles & No. $(\%)$ of opinion articles \\
\hline 1900-1919 & 0 & $1(0.7 \%)$ \\
\hline $1920-1949$ & 0 & $1(0.7 \%)$ \\
\hline 1950-1959 & 0 & 0 \\
\hline $1960-1969$ & $5(2.4 \%)$ & $9(6.3 \%)$ \\
\hline 1970-1979 & $24(11.7 \%)$ & $19(13.3 \%)$ \\
\hline 1980-1989 & $20(9.8 \%)$ & $18(12.7 \%)$ \\
\hline 1990-1999 & $26(12.7 \%)$ & $14(9.9 \%)$ \\
\hline $2000-2009$ & $42(20.5 \%)$ & $37(26.1 \%)$ \\
\hline $2010-2018$ & $88(42.9 \%)$ & $43(30.3 \%)$ \\
\hline Study design or publication type & No. $(\%)$ of non-opinion articles & \\
\hline Cross-sectional studies & $85(41.5 \%)$ & \\
\hline Survey-based & 63 & \\
\hline Review & $34(16.6 \%)$ & \\
\hline Narrative & 30 & No. $(\%)$ of opinion articles \\
\hline Case report or case series & $22(10.7 \%)$ & $N / A$ \\
\hline Case-control & $19(9.3 \%)$ & \\
\hline Cohort studies & $14(6.8 \%)$ & \\
\hline Interventiont & $13(6.3 \%)$ & \\
\hline Othert† & $18(8.8 \%)$ & \\
\hline
\end{tabular}

†Publications about an intervention at minimum describe the intervention.

†+Other study designs included: qualitative studies or psychological autopsy ( $n=8$ ), validation or evaluation of a survey instrument or screening question (3), news coverage (4), poetry (1), a discussion guide (1), or a correction (1).

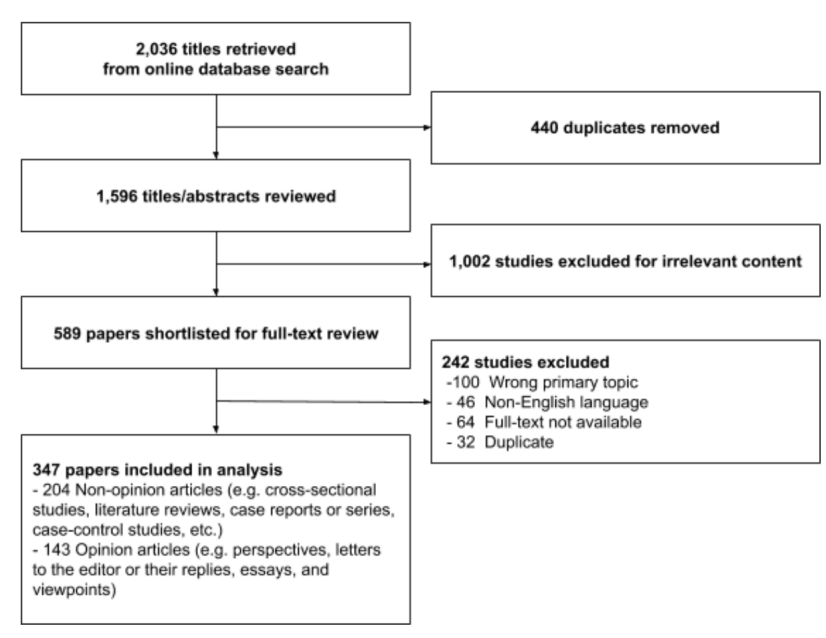

Figure 1. PRISMA diagram of study selection for inclusion

United Kingdom, Finland, Norway, Sweden, Italy, Japan, Canada, China, Denmark, Hungary, Brazil, Egypt, Germany, Lebanon, Pakistan, Poland, Taiwan, Austria, Belgium, Bosnia and Herzegovina, India, Iran, Malaysia, Nepal, New Zealand, Portugal, Serbia, South Korea, Spain, Thailand, Turkey, and the United Arab Emirates. Some countries have only published opinion articles about the subject, including Israel, Nigeria, and Pakistan. Six articles were opinion articles that contained no information about the country of origin.

\section{Ascertaining Suicidal Behaviors}

\section{Estimating Suicide Incidence}

Suicide is estimated to occur at a higher rate among physicians than the general population and perhaps even other professions (Schernhammer and Colditz 2004; Gold, Sen, and Schwenk 2013); however, estimates by profession vary (Peterson et al. 2018). Death by suicide was the only primary topic in 108 (31.1\%) of all articles. Non-opinion articles primarily sought to estimate epidemiology of suicidal behaviors among physician populations. In other words, death by suicide was most often studied among attending physicians because of availability of data on occupation and death, particularly in vital statistics or death certificates. However, the tools used to perform such estimates varied. Deaths by suicide were most frequently estimated based on 9th or 10th Revision of the International Classification of Diseases (ICD-9 or ICD-10) codes on death certificates. 
Table 2. Methods of ascertainment of suicidal behaviors and related risk factors for 204 non-opinion publications

\begin{tabular}{|c|}
\hline Methods of ascertainment \\
\hline Suicide death \\
\hline Death certificates (vital statistics by U.S. state or non-U.S. country) \\
\hline Forensic, pathology, or autopsy reports, for example, from a medical examiner's office \\
\hline Medical chart reviews of physician patients \\
\hline Professional membership masterfiles \\
\hline Obituaries published in journals (e.g. JAMA) \\
\hline Family confirmation or interviews \\
\hline Suicide attempt \\
\hline Paykel's Instrument (assesses suicidal ideation and suicide attempts) \\
\hline Beck Hopelessness Scale \\
\hline Investigator-developed question(s) or questionnaire \\
\hline Suicidal thoughts or ideation \\
\hline Patient Health Questionnaire 9 \\
\hline Beck Scale for Suicidal Ideation \\
\hline Acquired Capability for Suicide Scale \\
\hline Self-harm Behavior Questionnaire \\
\hline Suicidal Behaviors Questionnaire \\
\hline Investigator-developed question(s) or questionnaire \\
\hline
\end{tabular}

Other commonly used sources of data included membership masterfiles from physician organizations or associations (Juel, Mosbech, and Hansen 1999), published obituaries, and charts from medical records or forensic reports (Table 2). These data are primarily limited by potential undercoding. Undercoding can result from deaths being coded as accidental deaths, for example, leading to underestimation of the actual incidence of suicides among physicians. In an editorial, one author notes, "Suicide is a way to die and not a cause of death. And there are several means to this end: the ICD-10 lists at least 31 different ways to perform a suicide" (Aasland 2013). Rimpelä et al. articulated this in 1987 also: "Differentiation between suicide, accident, poisoning, and violence as a cause of death is often difficult, and suicide might sometimes be falsely, even deliberately, classified as an accident and even differently in different occupational groups" (Rimpelä et al. 1987).

Suicides are typically reported as a suicide mortality rate (SMR) in epidemiologic literature, which is the number of deaths by suicide per 100,000 person-years. A suicide rate ratio can be calculated by dividing the SMR among physicians, or a subpopulation thereof, and dividing by a comparison group, such as the general population. Despite these standardized manners of suicide reporting, included papers showed inconsistencies in reporting, often reporting a crude mortality rate, which is calculated by the absolute number of physician suicides divided by the number of years in a study period, then reported per 100,000 physicians. For example, in 1968, Craig and Pitts counted 228 suicides among physicians based on the obituary materials collected by the Deaths Editor of the Journal of the American Medical Association between May 1965 and May 1967 (Craig and Pitts 1968). Combined with an estimation of approximately 296,000 physicians in the U.S. at the time, this resulted in a crude annual suicide rate of 38.4 per 100,000 physicians (Craig and Pitts 1968). Multiplying this crude annual suicide rate and the U.S. physician population of approximately 953,000 , which was reported by a 2016 census from the Federation of State Medical Boards, leads to an estimate of 366 physician deaths by suicide annually.

Underreporting undermines the accuracy of physician suicide incidence estimates using death certificates, membership files, and medical charts. Surveys also can lead to underreporting. One study surveyed the deans of 116 medical schools in the 1970s about medical student suicides; 88 respondents reported 52 medical student suicides between 1970 and 1978 (PepitoneArreola-Rockwell, Rockwell, and Core 1981). Another approach to studying physician suicides is psychological autopsy, in which a psychological profile about a person is constructed after their death. Time-intensive and not a standard practice, psychological autopsy involves collecting information through interviews of relatives and healthcare professionals, along with data from forensic examinations, police investigations, psychiatry, medical and social agency records, and any other information available, such as suicide notes (Lindeman et al. 1998). Such an approach can elucidate potential contributors to an individual's death, providing detailed contextual information, their life circumstances, and how they managed such circumstances 
up until their death. However, psychological autopsies are not systematically applied in the setting of deaths by suicide. Case reports also may describe a psychological profile, in addition to medical and clinical aspects of the case (Lindeman et al. 1998; Hawton, Malmberg, and Simkin 2004; Koekkoek et al. 2008), but this was also infrequently published. In 2013, Gold et al. examined data from the U.S. National Violent Death Reporting System (NVDRS), which is a combination of information and data from death certificates, coroner and medical examiner reports, toxicology reports, and law enforcement reports (Gold, Sen, and Schwenk 2013), the only study to triangulate multiple data sources to estimate suicide incidence. The wide variety of data sources and methods of estimation suggest that there is no standard.

\section{Suicide Clusters}

Suicide clusters are suicides that occur near each other, typically with respect to time and geography. Suicide contagion refers to spread of information about a suicide via media and other channels, which can increase suicide risk in a community. Only three studies acknowledged these topics. Two opinion papers described suicide clusters that occurred in a short time span and in a focused geographic region, one in Winnipeg, Canada (Williams 1997) and another cited suicides in Australia that had been reported in news media (Clarke and McKee 2017). Both articles focused on intense or distressing working conditions as important factors in the suicide deaths, but did not elaborate further on suicide clusters. In fact, the Canadian article, along with one other case series of physicians who died by suicide while on probation in Oregon state (Crawshaw et al. 1980), used the term "epidemic" rather than "clusters." Nevertheless, these three articles referred to the concepts of suicide clusters and suggest contagion, even though they did not use these terms explicitly. These were articles that were tagged with the public health theme.

Suicide clusters also appeared to follow physician subpopulations, although numbers were small in such case series and opinion articles. Other physician subpopulations included, for example, immigrant physicians (Richings, Khara, and McDowell 1986), physician pilots (Cath 1974), and physicians who experienced war either as victims or as wartime medics (Bock et al. 2016; Likeman 2015). In 2016, Bock et al. described a case series of 62 Hungarian Jewish dermatologists during the Holocaust: some emigrated, some died during Nazi rule, and others survived (Bock et al. 2016). Three of these dermatologists died by suicide, which was "very common among the doctors (under the Nazi ordeal), especially those physicians of the older generation" (Bock et al.
2016). Another analysis described issues relevant to physician terrorists (Marvasti and Vahidy 2008), who are physicians who die by suicide and also experience "feelings of hopelessness, frustration, anger, and helplessness, as well as other kinds of psychic pain." Nevertheless, the authors contrast "clinical suicide" and "suicide bombing" by exploring their differing motivations (death of self vs. death and terrorization of others via death of self) and the relative lack of psychopathology and greater reliance on public perceptions of their actions among suicide bombers. This was not a population further described in this literature review.

\section{Estimating Suicidal Ideation and Attempts}

Overall, suicidal ideation was the second most studied thesis among articles included in this literature review, especially suicidal ideation among medical students. To assess suicidal ideation and attempts, surveys were most common; overall, 61 cross-sectional survey studies were performed (Table 1). Validated surveys are available to assess suicidal ideation (Table 2); however, investigator-developed items and surveys were also used. Only four studies compared physician subpopulations between countries. In the Health and Organization among University Hospital Physicians in Europe (HOUPE) study, investigators sought to compare suicidal thoughts and workrelated stressors between practicing physicians in Italy and Sweden (Fridner et al. 2009, 2011, 2012). Another study compared lifetime prevalence of suicidal thoughts among practicing physicians in Norway and Germany (Rosta and Aasland 2013).

Suicide attempts, in general, were poorly studied in any physician subpopulation, but suicidal behaviors among postgraduate trainees were the least studied of all, with resident physicians' behaviors studied more than fellows (Figure 2). Among the articles reviewed, only two validated tools, Paykel's Instrument and the Beck Hopelessness Scale, were identified that were specifically designed to assess suicide attempts; otherwise, investigators developed survey items to assess respondents' self-reported attempts.

\section{Physician-specific Risk Factors}

\section{Mental Health and Burnout}

Physicians' risk factors for suicidal behaviors, especially mental health disorders, are among the most common topics of study. Gold et al. examined the NVDRS data and identified certain risks unique to physicians compared to non-physicians: physicians were more likely to have a job problem preceding 
a. Primary outcome or thesis

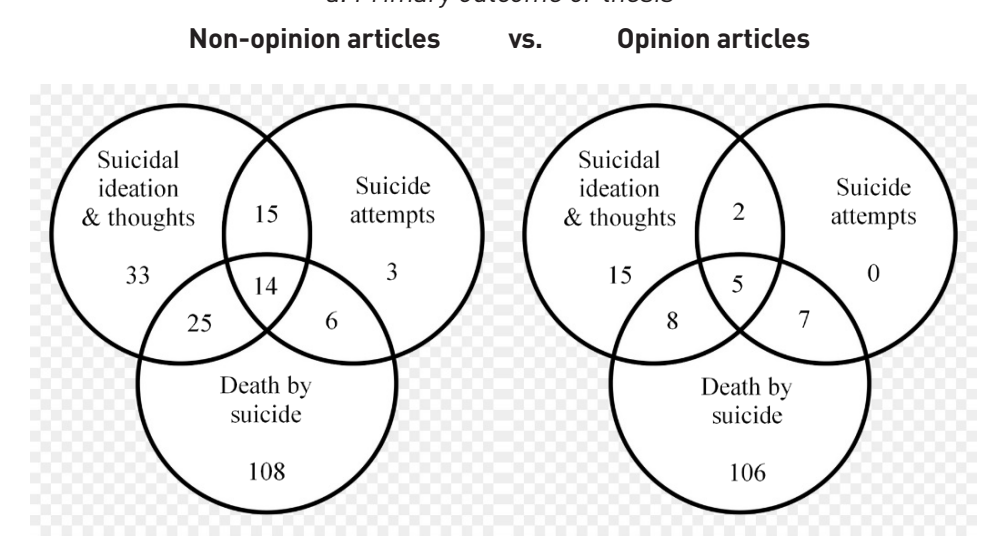

b. Population of study

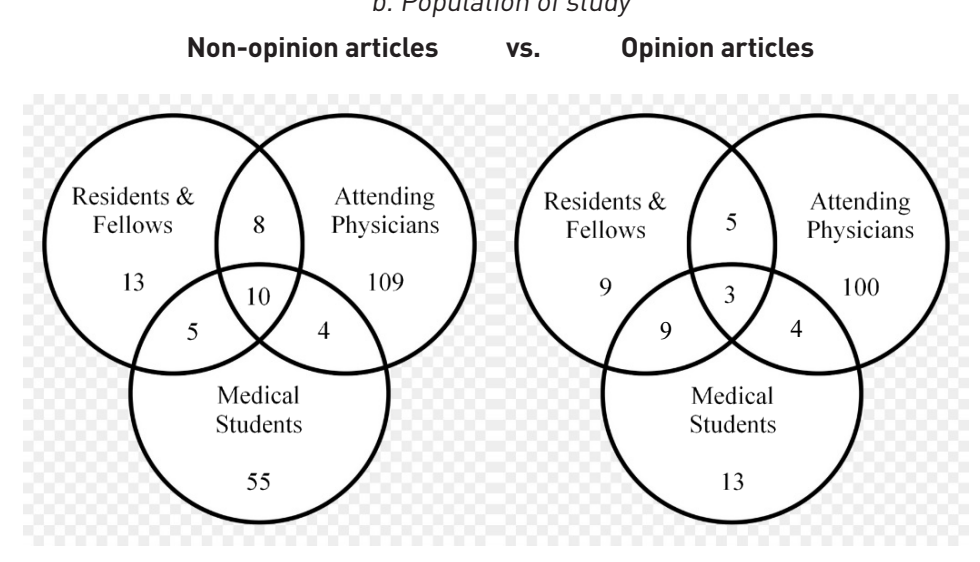

Figure 2. Death by suicide was the only and primary measure or thesis in a larger proportion of all articles; suicide attempts were the least well-studied or discussed (a). Attending or practicing physicians were the most studied population (b), especially when death by suicide was the primary thesis, while medical students were the second most studied population, with a focus on suicidal ideation (data not shown)

death by suicide and a greater likelihood of known mental health disorders, yet no accompanying increased likelihood of antidepressant therapy (Gold, Sen, and Schwenk 2013). Additional risk factors potentially include professional setbacks prior to suicide death, such as facing complaints (Crawshaw et al. 1980; Casey and Choong 2016), feeling overloaded, working long hours, being unable to cope with job responsibilities (Keith Hawton, Malmberg, and Simkin 2004), or experiencing disability as a result of medical illness (Cath 1974; Lindeman et al. 1998; Thomas 2014). Related to these conditions, physicians are also at high risk of burnout, which has been found to be associated with suicidal ideation in U.S. medical students (Dyrbye et al. 2008) and Dutch residents (Van Der Heijden et al. 2008), although no direct relationship between burnout and death by suicide has been established. To assess these risk factors, a variety of validated questionnaires were used to inquire about general health, burnout and stress, mental health (e.g. depression, anxiety or insomnia), substance use including alcohol use, and other measures of career, work, personality, and other life experiences (Table 2). Additionally, investigatordeveloped survey questions were also used, for example, to assess attitudes toward suicidal behaviors of a peer.

Because the earliest publications about physician suicide suggested an increased incidence compared to the general population, certain theories have been applied to attempt to explain the increased suicide risk among physicians. For example, Fink-Miller applied the interpersonal psychological theory of suicidal behavior (IPTS) (Cornette et al. 2009; FinkMiller 2015a) to physician suicide. The IPTS posits three necessary and sufficient precursors to death by suicide: (1) thwarted belongingness, a feeling of disconnection with others; (2) perceived burdensomeness, a miscalculation that one's death would relieve burdens on others; and (3) acquired capability, habituation to previously provoked fear responses, including losing the fear of pain involved in taking one's life. This can 
stem from repeated exposure to painful or provocative stimuli, including events triggering second victimization, such as patients' poor outcomes, death, and suffering. This can then lead to desensitization when exposed to death in general.

Role strain describes physician risks as a result of their direct work environment or professional norms; a mismatch between social and institutional norms and the physician's roles can manifest as an unrealistic expectation of perfect function at a maximum level of competence (DeSole, Singer, and Aronson 1969). Professional self-image and identity, along with selfstigma, are also considered relevant mediating themes (Cath 1974; Lindeman et al. 1998; Legha 2012).

\section{Specialty of Practice}

Early studies of suicide rates by specialty suggested that psychiatry and anesthesiology had the highest suicide rates (Cornette et al. 2009). A 2014 case series of 87 physician suicides in Japan demonstrated that internists (24.1\%), psychiatrists (18.4\%), pediatricians (6.9\%), and anesthesiologists (5.7\%) were most commonly affected specialties, although $16 \%$ of cases had unknown specialty (Hikiji and Fukunaga 2014). Small case series in Thailand and China had to few cases to draw a conclusion about specialties (Wang, Liu, and Xu 2017; Yasri and Wiwanitkit 2017), a commonly encountered issue in comparing specialties' suicide rates. Eighteen non-opinion articles published since 2010 described either cross-sectional survey studies of burnout and its correlation with suicidal ideation per specialty or additional case reports or series of physician suicide deaths. Generally, the findings about which specialties may be at higher risk than others have mixed findings due to data limitations in ascertaining suicide rates, small samples, and inappropriate comparisons or assumptions in data interpolation (Bruce et al. 1968; Bergman 1979; Neil et al. 1987; Swanson, Roberts, and Chapman 2003).

Means of suicide death was also a topic examined in some studies. In a U.K. study examining suicide means, 10 (50\%) of 20 anesthesiologists died by overdosing with anesthetic agents compared to other doctors, for example, 2 (16.6\%) of 12 surgeons and 10 (4.5\%) of 223 physicians overall died by overdose (Hawton et al. 2000). In the 2014 case series published from Japan, authors found a similar trend in studying suicide deaths across specialties (Hikiji and Fukunaga 2014); four of five anesthesiologists (of a total of 87 physicians) used drugs as means of suicide. Based on the IPTS, one proffered but unstudied hypothesis is that some medical specialties may possess more acquired capability, or acquired fearlessness about death, than others (Fink-Miller 2015a, 2015b).

\section{Specialized Knowledge and Access}

The access and knowledge hypothesis is a commonly discussed risk factor for suicide death among physicians. Physicians acquire specialized medical knowledge of the human body and have access to the means (e.g. prescription drugs) that can cause lethal self-harm. Observational studies of means of suicide death suggest that firearm, prescription drug overdose, and hanging are among the most common methods used by physicians (Cornette et al. 2009; Rimpelä et al. 1987; Swanson, Roberts, and Chapman 2003), although this varies by country. Psychological autopsies are consistent with the access and knowledge hypothesis. One set of psychological autopsies in the United Kingdom examined 38 physician suicides, finding that 28 of the physicians died by self-poisoning and 11 by selfinjury (other than poisoning), as 1 physician used both methods (Keith Hawton, Malmberg, and Simkin 2004). In a Finnish psychological autopsy of seven physician suicides, only two had previous suicide attempts, suggesting that physicians may be more likely to cause self-harm leading to death by suicide; in other words, physicians who die by suicide may not have had any prior suicide attempt, which is a risk factor in the general population (Lindeman et al. 1998). Self-treatment or selfprescription is also a concerning contributor due to specialized access to controlled substances, as "medical doctors exploit their profession for purpose of self-treatment" (Lindeman et al. 1998).

\section{Personality Traits, Upbringing, and Cultural Context}

Personality and life experience prior to medical training might also contribute to physician suicide risk, although they are poorly studied. In a prospective study of Norwegian medical students, a version of the Basic Character Inventory, originally developed in 1920, was used to measure major personality dimensions, including neuroticism, control, and extroversion (Tyssen et al. 2001, 2004). The control personality trait, or the degree of compulsiveness, was independently linked to suicidal ideation; and more neuroticism as a medical student, which is linked to the vulnerability personality trait including sensitivity to other people's opinions and criticism, independently predicted more serious suicidal ideations and planning in the first two postgraduate years (Graves and Thomas 1991; Tyssen et al. 2004, 2001).The reality weakness personality trait, more commonly associated with serious psychiatric pathology such as paranoid traits, predicted a transition from suicide ideation to planning (Tyssen et al. 2004).

One editorial speculates about the influence of adverse childhood experiences on risk for physician suicide (Johnson 
1991). A South Korean study found a more than threefold risk of lifetime suicidal ideation, planning, and attempts among medical students who experienced emotional abuse early in life, characterized by "a continuously cold and uncaring parental attitude" (Jeon et al. 2009). In China, medical students were surveyed about parental relationships and parenting communication styles, hypothesizing that this could be a highly influential aspect of the student's character (Sun et al. 2017). The study found that for Chinese medical students, a good relationship with parents was statistically significantly associated with less suicidal ideation, plans, and attempts.

Some studies sought to identify risk factors unique to their cultural context. Researchers in the United Arab Emirates collaborated with Eskin (Eskin et al. 2011) to again assess medical students' religiosity and their attitudes toward suicide (Amiri et al. 2013). In this study, investigators suggested that the Islamic faith may serve as a protective factor against suicidal thoughts and death by suicide among their medical students. In Pakistan, a study of suicidal ideation among medical students included religion as a demographic characteristic, but did not otherwise include religion in further analyses (Osama et al. 2014). Among opinion articles, certain conceptualizations of suicide also varied. For example, in one commentary from Japan, two concepts directly link overwork with death: karoshi (death due to overwork) and karojisatsu (suicide due to overwork) are considered causes of death in the Japanese culture (Hiyama and Yoshihara 2008), but nowhere else in the world.

\section{Gender}

Early studies in the 1970s and earlier explicitly excluded female and minority physicians (Thomas and Greenstreet 1973; Ullmann et al. 1991; Graves and Thomas 1991). Results published in 1999 from the Women Physicians' Health Study, which surveyed a sample of women physicians from the American Medical Association masterfile (Frank and Dingle 1999), described previous studies that reported an odds ratio as high as 4 for women physician suicides compared to other categories of women, but that such studies were based on small numbers of suicide deaths. This study found that women physicians had similar rates of depression (19.5\%) compared to women in the general population, but $1.5 \%$ of women physicians attempted suicide compared to $2.9 \%$ of women in the general population (Frank and Dingle 1999); the authors postulated that women physicians may have less suicidal intent, and therefore less suicide attempts, or it could be that they have a higher rate of completion than women in the general population, and therefore also less suicide attempts since attempts more often resulted in death.
In 2004, Schernhammer performed a systematic review and meta-analysis, concluding that the suicide rate ratio for women physicians was 2.27 compared to the general women population and for male physicians was 1.41 compared to the general male population (Schernhammer and Colditz 2004). In 2013, a Polish study of perimenopausal female physicians examined sociodemographic and lifestyle variables' relationship to participants' subjective sense of health, including suicidal ideation. Eight of 221 participants reported suicidal thoughts, which was statistically significantly correlated with poorer subjective sense of health (Gojdź et al. 2013). Another study in Pakistan appeared to show no gender difference in terms of rates of suicidal ideation among medical students (Ghazanfar et al. 2015).

Little data is known on suicide among physicians of gender minorities, as there is only one perspective piece written by a nurse who wrote about her transgender child who died by suicide (Dippo 2007).

\section{Themes in Physician Suicide Literature}

This scoping literature review revealed several themes in physician suicide literature, with greatest attention to identifying risk factors such as mental health. Culture of practice and context of suicide, which include, for example, mental health stigma, physician attitudes toward suicide, and job conflicts, also were subjects of increased focus. These and the remaining themes identified are illustrated in Figure 3, where the most common themes are positioned at the broadest (top) level of an inverted pyramid. With each successive level of the inverted pyramid, fewer papers describe such issues. We chose an inverted pyramid to illustrate how the weight of the risk factors for physician suicides balances precariously over the vertex, where less attention is paid on postvention and public health initiatives for surveillance and prevention. This imbalance quickly identifies potential areas for further work. Themes such as suicide as a public health issue, postvention, and legal issues were far less studied than others.

In the second level of the framework are epidemiologic and demographic focuses for study, which were previously described in the section on Physician-specific Risk Factors. Along with these subjects are a relatively lesser focus on substance use, compared to other risk factors such as mental health, and on developing educational curricula to address knowledge gaps about suicide and its prevention. Wellness is an increasingly popular topic for publication on this level of the framework. In the third level of the framework are prevention approaches. Thirteen articles described interventions with 


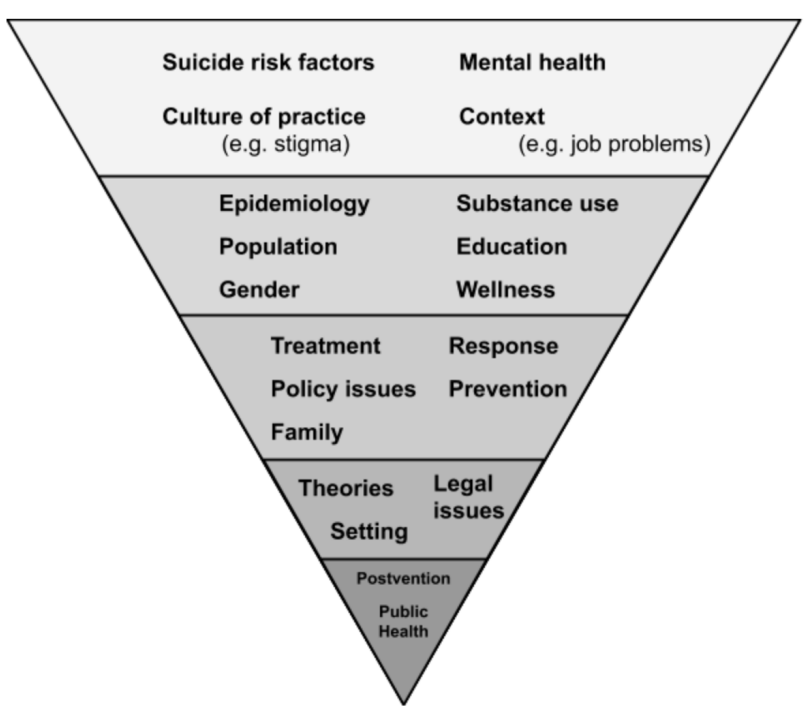

Figure 3. Framework of common publication themes on physician suicide

a primary aim of preventing physician suicides. Frequently, programs were implemented as an organizational response to a physician suicide. Five interventions implemented the American Foundation for Suicide Prevention's Interactive Screening Program for suicide prevention (Ey et al. 2016; Haskins et al. 2016) as a component of a larger initiative to promote physician well-being; three of the five came from the same institution (Moutier et al. 2012; Downs et al. 2014; Zisook et al. 2016). Only 1 of 13 was a randomized controlled trial of a web-based screening program (Guille et al. 2015).

Treatments and responses to physician suicide were discussed as frequently as prevention; treatments and responses differed because treatments tended to focus on individual physician treatment for suicidal behaviors or related mental health disorders, and responses tended to focus on a small group, physician health program, or medical board responses to individual circumstances. For example, Young et al. described the difficult grieving process for a healthcare team after the death of a physician (Young et al. 1989). Patients were told that the physician who had died "was not available," trust between staff and administrators eroded, morale decreased, and grieving, guilt, and other negative consequences remained unaddressed until 6 weeks after the physician's death (Young et al. 1989). The process of facilitating a normal grieving process after a suicide death has occurred requires active planning, called postvention. In another study by Kaltreider et al., 20 medical students were interviewed after the death of a classmate by suicide (Kaltreider 1990). This qualitative study found that students experienced intense, intrusive, and persistent thoughts and emotions relating to their classmate's death, sometimes lasting for months. Proximity to the site of the death, prior exposure to another suicide previously, or familiarity with depression in themselves or family seemed to increase these effects.

Legal and policy issues are increasingly recognized as affecting physician health and well-being and appear in the third and fourth levels of Figure 3. Physicians may avoid seeking mental health treatment, avoid self-report, and self-treat mental health and other health issues (Johnston 1979; Feeney et al. 2016), out of fear of reputational damage or concern about perceived weakness or impairment (Worley 2008). Licensure application questions could be improved (Worley 2008) and compassionate, confidential assistance programs, such as one implemented in the United Kingdom in 2010, could offer bespoke services to physicians who might be considered at risk of suicide (Feeney et al. 2016). In 2015, the United Kingdom's General Medical Council was recommended to fund a pilot program that would include developing a national support service for doctors (Meerten et al. 2011). However, no literature was found to describe such policies in other countries.

Only three articles describe suicide clustering and suicide contagion (Williams 1997; Clarke and McKee 2017; Crawshaw et al. 1980). With minimal coverage of suicide clusters in physician suicide literature, there is a notable absence also of related concepts that have been previously described in suicidology literature, such as Werther syndrome or copycat suicide. These are unique public health concepts pertaining to suicide. Because postvention and public health approaches in physician suicide are poorly implemented and studied, both concepts were positioned at the bottom of the inverted pyramid (Figure 3).

\section{DISCUSSION}

As a scoping literature review, this review did not include a quality assessment of quantitative evidence from included papers nor did it perform a meta-analysis or any statistical comparisons of published evidence, which would be characteristic of a systematic review (The Joanna Briggs Institute 2015). More papers on physician suicide have been published over the last two decades than before. This follows an overall trend in published literature on physician well-being and may also reflect growing public recognition of and decreasing stigma relating to suicide. Furthermore, the proportion of opinion articles published is lower in the recent past compared to previously, indicating growing application of contemporary statistical and scientific methods to the study of physician suicide. Nonetheless, themes identified reveal opportunities for further work. The inverted 


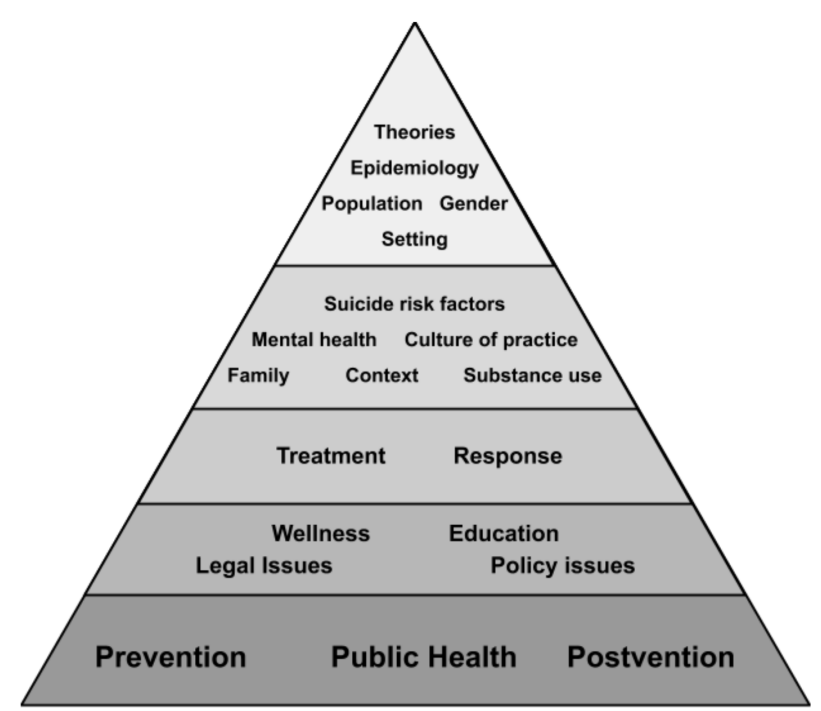

Figure 4. Proposed framework to highlight priorities for continued work on physician suicide

pyramid framework (Figure 4) suggests that there is a dearth of work on examining physician suicide using typical public health approaches to investigate suicide clusters.

Figure 4 offers a proposed framework that highlights priorities for continued work on physician suicide. This framework highlights the potential for developing an organized public health approach to preventing physician suicide. The pyramid's base identifies several areas for immediate, targeted action.

First, mandatory reporting, an approach used for workplace injury reporting, could improve surveillance of physician deaths by suicide (prevention). This also offers the potential for improved incidence detection and investigation of possible suicide clusters (public health). Furthermore, identifying minimum acceptable community standards of validated instruments used to assess suicidal ideation and attempts (prevention, public health) would also facilitate more accurate incidence estimates of such suicidal behaviors.

Fortunately, institution-based prevention programs with an explicit aim to prevent physician suicide have already been developed. More widespread development and implementation of evidence-based screening and service provision for suicide risk factors (prevention) are also still needed beyond institutionbased initiatives for the greatest impact. Implementation and dissemination of postvention best practices and related programs are the necessary components to both support suicide loss survivors and prevent suicide clusters or contagion (postvention). They are as follows:
- increased education in the healthcare community about suicide warning signs and prevention (education, wellness);

- standardized education in the medical community about appropriate reporting on suicides to prevent suicide contagion (education); and

- reduction of barriers to help-seeking behavior and reduction of systematic stigma in licensing and investigative processes (policy issues, legal issues).

Top levels in Figure 4 include continued study of persistent risk factors, contextual and cultural challenges, social factors like family, and health inequities resulting from gender, immigrant, or other minority status, among other concerns. Currently available information is insufficient to draw conclusions about physician subgroups or their cultural or health system contexts. Such information on understudied physician subgroups could better inform future revisions of public health, prevention, and postvention programs to include diversity-sensitive suicide prevention approaches.

Additional articles have been published on physician suicide since the end of the last search period of April 2018. The necessity of accurately estimating physician suicide incidence remains a vital undertaking (Dutheil et al. 2019; Duarte et al. 2020). Editorials also demonstrate increasingly diverse and important views on the subject, including those of medical students (Chen 2019; Isaacs 2020), interns (Bullock 2020), or practicing physicians (Lynch 2020) who recount first-hand experiences with suicidal ideations or attempts. Others are physician suicide loss survivors (Hagens 2020) or advocates or researchers who publish about the impact of physician suicide (Poorman 2019; Gold and Schwenk 2020). The first-hand accounts are increasingly common and are a promising signal of potentially decreasing stigma in the medical community around discussing personal experiences of physician suicidal behaviors. More recently, with the COVID-19 pandemic in 2020, there may be a destigmatization of mental illness that could lead to an increasing attention and willingness in the medical community to address physician suicidality. This presents emerging opportunities for the study and prevention of suicide among physicians (Reger, Stanley, and Joiner 2020).

The strengths of this scoping literature review are its breadth and inclusiveness in examining multiple article types published in scholarly journals. However, due to the volume of citations generated by the searches, we excluded grey literature (e.g. conference proceedings, poster presentations, etc.) and snowballing of references was not performed. Additionally, because physician suicide involves multiple disciplines, additional electronic databases in future searches may be 
needed to capture broader perspectives on physician suicide. Finally, excluding non-English language publications may have led to overrepresentation of countries where English is the official language. Among the 46 non-English language papers excluded (Figure 1), potentially relevant papers were published in German, Spanish, Dutch, Finnish, Japanese, Chinese, French, Swedish, and Hungarian, which could reveal relevant themes in physician suicide, including cultural or health system context. Future studies could identify opportunities for crossdisciplinary and cross-cultural learning and suicide prevention.

\section{CONCLUSION}

This scoping review offers a landscape view of physician suicide literature and opportunities for further work on physician suicide prevention. Interventions are needed at multiple levels to mitigate the risks of physician suicide, which could begin with an organized public health approach. As a part of such an approach, consistency and reliability of data and information about physician suicides could be improved. Data limitations partly contribute to these issues. For example, annual rates of physician suicide reported and quoted may result from extrapolated estimates from old data, such as those collected by Craig and Pitts in 1968 (Craig and Pitts 1968). Reliable and trackable data and information can provide more continuously updated insights into the actual SMR ratios of physician suicide compared to other populations (Leung et al. 2019). Also, systems could be developed for better surveillance of physician suicides, including studying and tracking possible suicide clusters or contagion. These may improve investigation and interventions for the benefit of physicians' and public health. Physician suicide should be approached as a public health issue and as a shared responsibility between individuals and institutions to prevent physician deaths by suicide.

\section{ACKNOWLEDGMENTS}

The authors wish to acknowledge Dr. Christine Moutier and Dr. Srijan Sen for their critical review and feedback on the manuscript, as well as Dr. Matthew Goldberg for his early contributions to the background and initial design considerations for this review.

\section{AUTHOR CONTRIBUTIONS}

TIL, SP, and CYAC designed the study and performed study selection. RS performed the literature search. TIL and SP extracted data, and TIL, SP, and CYAC interpreted the data. TIL drafted the manuscript, except for section 2 which was drafted by RS, and the entire manuscript was produced with critical revisions and important intellectual content from all authors.

\section{ETHICAL APPROVAL}

Not applicable

\section{FUNDING}

This work was supported by a Mapping the Landscape Literature Review grant (2017-2019) from the Arnold P. Gold Foundation Research Institute. The Arnold P. Gold Foundation Research Institute had no role in the study design, data collection and analysis, writing of the report, or decision to submit the manuscript for publication.

\section{INFORMED CONSENT}

Not applicable

\section{STUDY REGISTRATION}

This scoping literature review protocol was registered with PROSPERO.

\section{DATA AVAILABILITY STATEMENT}

The raw data supporting the conclusions of this manuscript will be made available by the authors, without undue reservation, to any qualified researcher. A complete reference list of all included full-text articles is available in Appendix 2. 


\section{REFERENCES}

Aasland, Olaf Gjerløw. 2013. “Physician Suicide-Why?” General Hospital Psychiatry 35 (1): 1-2. https://doi.org/10.1016/j. genhosppsych.2012.09.005.

Aasland, Olaf Gjerløw, Øivind Ekeberg, and Tore Schweder. 2001. "Suicide Rates from 1960 to 1989 in Norwegian Physicians Compared with Other Educational Groups." Social Science \& Medicine 52 (2): 259-65. https://doi.org/10.1016/S0277-9536(00)00226-4.

Amiri, Leena, Martin Voracek, Said Yousef, Alaa Galadari, Salem Yammahi, Mohammad Reza Sadeghi, Mehmet Eskin, and Kanita Dervic. 2013. "Suicidal Behavior and Attitudes among Medical Students in the United Arab Emirates." Crisis 34 (2): 116-23. https://doi.org/10.1027/0227-5910/a000170.

Arksey, Hilary, and Lisa O'Malley. 2005. “Scoping Studies: Towards a Methodological Framework." International Journal of Social Research Methodology 8 (1): 19-32. https://doi.org/10.1080/1364 557032000119616 .

Bergman, Jerry. 1979. "The Suicide Rate Among Psychiatrists Revisited." Suicide and LifeDThreatening Behavior 9 (4): 219-26. https://doi.org/10.1111/j.1943-278X.1979.tb00440.x.

Bock, Julia, Walter H.C. Burgdorf, Leonard J. Hoenig, and Lawrence Charles Parish. 2016. "The Fate of Hungarian Jewish Dermatologists during the Holocaust: Part 2: Under Nazi Rule." Clinics in Dermatology 34 (6): 768-78. https://doi.org/10.1016/j. clindermatol.2016.06.002.

Bruce, David L., K. Arne Eide, Harry W. Linde, and James E. Eckenhoff. 1968. "Causes of Death among Anesthesiologists: A 20-Year Survey." Anesthesiology 29 (3): 565-69.

Bullock, Justin L. 2020. "Suicide - Rewriting My Story." New England Journal of Medicine 382 (13): 1196-97. https://doi. org/10.1056/NEJMp1917203.

Casey, David, and Kartina A. Choong. 2016. “Suicide Whilst under GMC's Fitness to Practise Investigation: Were Those Deaths Preventable?" Journal of Forensic and Legal Medicine 37: 22-27. https://doi.org/10.1016/j.jflm.2015.10.002.

Cath, Stanley H. 1974. "Some Human Factors in the Flying Physician." Aerospace Medicine 45 (11): 1298-1302.

Chen, Hsuan-hsiu Annie. 2019. “Isolated, Together." Pediatrics 144 (3): e20191210. https://doi.org/10.1542/peds.2019-1210.
Clarke, Rachel, and Martin McKee. 2017. "Suicides among Junior Doctors in the NHS." BMJ (Online) 357: 1-2. https://doi. org/10.1136/bmj.j2527.

Cornette, Michelle M., Terri A. Deroon-Cassini, Gregory M. Fosco, Richard L. Holloway, David C. Clark, and Thomas E. Joiner. 2009. "Application of an Interpersonal-Psychological Model of Suicidal Behavior to Physicians and Medical Trainees." Archives of Suicide Research13(1): 1-14.https://doi.org/10.1080/13811110802571801.

Craig, Alan G., and Ferris N. Pitts. 1968. "Suicide by Physicians." Diseases of the Nervous System 29 (11): 763-72. http://www.ncbi. nlm.nih.gov/pubmed/5717292.

Crawshaw, Ralph, John A. Bruce, Patricia L. Eraker, Marvin Greenbaum, James E. Lindemann, and David E. Schmidt. 1980. "An Epidemic of Suicide among Physicians on Probation." JAMA 243 (19): 1915-17. https://doi.org/10.1001/jama.243.19.1915.

DeSole, Daniel E., Philip Singer, and Samuel Aronson. 1969. “Suicide and Role Strain Among Physicians." International Journal of Social Psychiatry 15 (4): 294-301.

Dippo, Jeanette. 2007. "A Mother's Story." Minnesota Medicine, no. December: 28-31.

Downs, Nancy, Wendy Feng, Brittany Kirby, Tara McGuire, Christine Moutier, William Norcross, Marc Norman, Ilanit Young, and Sid Zisook. 2014. "Listening to Depression and Suicide Risk in Medical Students: The Healer Education Assessment and Referral (HEAR) Program." Academic Psychiatry 38 (5): 547-53. https://doi. org/10.1007/s40596-014-0115-x.

Duarte, Dante, Mirret M. El-Hagrassy, Tiago Castro e Couto, Wagner Gurgel, Felipe Fregni, and Humberto Correa. 2020. “Male and Female Physician Suicidality." JAMA Psychiatry 02129 (March): 1-11. https://doi.org/10.1001/jamapsychiatry.2020.0011.

Dutheil, Frédéric, Claire Aubert, Bruno Pereira, Michael Dambrun, Fares Moustafa, Martial Mermillod, Julien S. Baker, Marion Trousselard, François-Xavier Lesage, and Valentin Navel. 2019. "Suicide among Physicians and Health-Care Workers: A Systematic Review and Meta-Analysis." Edited by Takeru Abe. PLOS ONE 14 (12): e0226361. https://doi.org/10.1371/journal. pone.0226361.

Dyrbye, Liselotte N, Matthew R Thomas, F Stanford Massie, David V Power, Anne Eacker, William Harper, Steven Durning, 
et al. 2008. "Burnout and Suicidal Ideation among U.S. Medical Students." Annals of Internal Medicine 149 (5): 334-41. https://doi. org/149/5/334 [pii].

Eskin, Mehmet, Martin Voracek, Stefan Stieger, and Vesile Altinyazar. 2011. "A Cross-Cultural Investigation of Suicidal Behavior and Attitudes in Austrian and Turkish Medical Students." Social Psychiatry and Psychiatric Epidemiology 46 (9): 813-23. https://doi.org/10.1007/s00127-010-0254-7.

Ey, Sydney, Mary Moffit, J. Mark Kinzie, and Patrick H. Brunett. 2016. "Feasibility of a Comprehensive Wellness and Suicide Prevention Program: A Decade of Caring for Physicians in Training and Practice." Journal of Graduate Medical Education 8 (5): 74753. https://doi.org/10.4300/JGME-D-16-00034.1.

Feeney, Sinéad, Kevin O'Brien, Neasa O'Keeffe, Anna Nic Con lomaire, Maureen E. Kelly, John McCormack, Genevieve McGuire, and David S. Evans. 2016. "Practise What You Preach: Health Behaviours and Stress among Non-Consultant Hospital Doctors." Clinical Medicine, Journal of the Royal College of Physicians of London 16 (1): 12-18. https://doi.org/10.7861/ clinmedicine.16-1-12.

Fink-Miller, Erin L. 2015a. "An Examination of the Interpersonal Psychological Theory of Suicidal Behavior in Physicians." Suicide and Life-Threatening Behavior 45 (4): 488-94. https://doi. org/10.1111/sltb.12147.

Fink-Miller. 2015b. "Provocative Work Experiences Predict the Acquired Capability for Suicide in Physicians." Psychiatry Research 229 (1-2): 143-47. https://doi.org/10.1016/j.psychres.2015.07.055.

Frank, Erica, and Arden D Dingle. 1999. "Self-Reported Depression and Suicide Attempts among U.S. Women Physicians." The American Journal of Psychiatry 156 (12): 1887-94. https://doi. org/10.1176/ajp.156.12.1887.

Fridner, Ann, Karen Belkic, Massimo Marini, Daria Minucci, Luigi Pavan, and Karin Schenck-Gustafsson. 2009. "Survey on Recent Suicidal Ideation among Female University Hospital Physicians in Sweden and Italy (the HOUPE Study): Cross-Sectional Associations with Work Stressors." Gender Medicine 6 (1): 314-28. https://doi. org/10.1016/j.genm.2009.04.006.

Fridner, Ann, Karen Belkić, Massimo Marini, Marie Gustafsson Sendén, and Karin Schenck-Gustafsson. 2012. "Why Don't Academic Physicians Seek Needed Professional Help for Psychological Distress?" Swiss Medical Weekly 142 (JULY): 1-8. https://doi.org/10.4414/smw.2012.13626.
Fridner, Ann, Karen Belkić, Daria Minucci, Luigi Pavan, Massimo Marini, Birgit Pingel, Giovanni Putoto, Pierluigi Simonato, Lise T. Løvseth, and Karin Schenck-Gustafsson. 2011. “Work Environment and Recent Suicidal Thoughts among Male University Hospital Physicians in Sweden and Italy: The Health and Organization among University Hospital Physicians in Europe (HOUPE) Study." Gender Medicine 8 (4): 269-79. https://doi.org/10.1016/j. genm.2011.05.009.

Ghazanfar, Haider, Saad Hameed, Ali Ghazanfar, Joshua Rahat Aleman Bhatti, Ibad ul Haq, Rafeh Saeed, Muhammad Saeed Shafi, Ashraf Hussain, Arshad Javaid, and Sajida Naseem. 2015. "Suicidal Ideation among Pakistani Medical Students." Rawal Medical Journal 40 (4): 458-62.

Gojdź, Krzysztof, Monika Baロk-Sosnowska, Sebastian Kołodziej, and Violetta Skrzypulec-Plinta. 2013. "Quality of Life of Female Physicians Aged 45-55 Years." Przeglad Menopauzalny 17 (3): 213-15. https://doi.org/10.5114/pm.2013.36585.

Gold, Katherine J., and Thomas L. Schwenk. 2020. "Physician Suicide-A Personal and Community Tragedy." JAMA Psychiatry 47 (4): 461-74. https://doi.org/10.1001/jamapsychiatry.2020.0009.

Gold, Katherine J., Ananda Sen, and Thomas L. Schwenk. 2013. "Details on Suicide among US Physicians: Data from the National Violent Death Reporting System." General Hospital Psychiatry 35 (1): 45-49. https://doi.org/10.1016/j.genhosppsych.2012.08.005.

Graves, Pirkko Lauslahti, and Caroline Bedell Thomas. 1991. "Habits of Nervous Tension and Suicide." Suicide and LifeThreatening Behavior 21 (2): 91-105. https://doi.org/10.1111/ j.1943-278X.1991.tb00458.x.

Guille, Constance, Zhuo Zhao, John Krystal, Breck Nichols, Kathleen Brady, and Srijan Sen. 2015. “Web-Based Cognitive Behavioral Therapy Intervention for the Prevention of Suicidal Ideation in Medical Interns a Randomized Clinical Trial." JAMA Psychiatry 72 (12): 1192-98. https://doi.org/10.1001/ jamapsychiatry.2015.1880.

Hagens, John. 2020. "The Rocky Mountain Spartans." Canadian Medical Association Journal 192 (13): E347-48. https://doi. org/10.1503/cmaj.190701.

Haskins, Jessica, John G. Carson, Celia H. Chang, Carol Kirshnit, Daniel P. Link, Leslie Navarra, Lorin M. Scher, Andres F. Sciolla, Jeffrey Uppington, and Peter Yellowlees. 2016. "The Suicide Prevention, Depression Awareness, and Clinical Engagement Program for Faculty and Residents at the University of California, 
Davis Health System." Academic Psychiatry 40 (1): 23-29. https:// doi.org/10.1007/s40596-015-0359-0.

Hawton, K, A Clements, S Simkin, and A Malmberg. 2000. "Doctors Who Kill Themselves: A Study of the Methods Used for Suicide." QJM : Monthly Journal of the Association of Physicians 93 (6): 35157. http://www.ncbi.nlm.nih.gov/pubmed/10873184.

Hawton, Keith, Aslög Malmberg, and Sue Simkin. 2004. "Suicide in Doctors: A Psychological Autopsy Study." Journal of Psychosomatic Research 57 (1): 1-4. https://doi.org/10.1016/ S0022-3999(03)00372-6.

Heijden, Frank Van Der, Gea Dillingh, Arnold Bakker, and Jelle Prins. 2008. "Suicidal Thoughts among Medical Residents with Burnout." Archives of Suicide Research 12 (4): 344-46. https://doi. org/10.1080/13811110802325349.

Hem, Erlend, Nina T. Grønvold, Olaf Gjerløw Aasland, and Øivind Ekeberg. 2000. “The Prevalence of Suicidal Ideation and Suicidal Attempts among Norwegian Physicians. Results from a CrossSectional Survey of a Nationwide Sample." European Psychiatry 15 (3): 183-89. https://doi.org/10.1016/S0924-9338(00)00227-3.

Hikiji, Wakako, and Tatsushige Fukunaga. 2014. "Suicide of Physicians in the Special Wards of Tokyo Metropolitan Area." Journal of Forensic and Legal Medicine 22 (February): 37-40. https://doi.org/10.1016/j.jflm.2013.12.022.

Hiyama, T, and M Yoshihara. 2008. "New Occupational Threats to Japanese Physicians: Karoshi (Death Due to Overwork) and Karojisatsu (Suicide Due to Overwork)." Occupational and Environmental Medicine 65 (6): 428-29. https://doi.org/10.1136/ oem.2007.037473.

Isaacs, Kayla H. 2020. "The Mental Health Hazards of Reading About Physician Suicide." JAMA Internal Medicine 180 (4): 481. https://doi.org/10.1001/jamainternmed.2019.6520.

Jeon, Hong Jin, Myoung Sun Roh, Kyu Han Kim, Jeong Ryul Lee, Dongsoo Lee, Se Chang Yoon, and Bong Jin Hahm. 2009. "Early Trauma and Lifetime Suicidal Behavior in a Nationwide Sample of Korean Medical Students." Journal of Affective Disorders 119 (1-3): 210-14. https://doi.org/10.1016/j.jad.2009.03.002.

Johnson, W. D.K. 1991. “Predisposition to Emotional Distress and Psychiatric Illness amongst Doctors: The Role of Unconscious and Experiential Factors." British Journal of Medical Psychology 64 (4): 317-29. https://doi.org/10.1111/j.2044-8341.1991.tb01670.x.
Johnston, Gerald P. 1979. “Dangers of Self-Prescription." Journal of the Indiana State Medical Association 72 (8): 570-72.

Juel, Knud, Johannes Mosbech, and Eva Støttrup Hansen. 1999. "Mortality and Causes of Death among Danish Medical Doctors 1973-1992." International Journal of Epidemiology 28 (3): 456-60. https://doi.org/10.1093/ije/28.3.456.

Kaltreider, Nancy B. 1990. "The Impact of a Medical Student's Suicide." Suicide \& Life-Threatening Behavior 20 (3): 195-205. http://www.ncbi.nlm.nih.gov/pubmed/2238012.

Koekkoek, Bauke, John G. Gunderson, Ad Kaasenbrood, and Thomas G. Gutheil. 2008. "Chronic Suicidality in a Physician: An Alliance yet to Become Therapeutic." Harvard Review of Psychiatry 16 (3): 195-204. https://doi.org/10.1080/10673220802167832.

Legha, Rupinder K. 2012. "A History of Physician Suicide in America." Journal of Medical Humanities 33 (4): 219-44. https:// doi.org/10.1007/s10912-012-9182-8.

Leung, Tiffany I., Sima Pendharkar, Chwen-Yuen Angie Chen, and Michel Dumontier. 2019. "Finding the Evidence Base Using Citation Networks: Do 300 to 400 U.S. Physicians Die by Suicide Annually?" In AMIA Symposium Proceedings. Washington, DC.

Likeman, Robert K. 2015. "Physician, Heal Thyself." The Medical Journal of Australia 202 (7): 383. https://doi.org/10.5694/ mja15.00080.

Lindeman, Sari, Hannu Heinänen, Erkki Väisänen, and Jouko Lönnqvist. 1998. "Suicide among Medical Doctors: Psychological Autopsy Data on Seven Cases." Archives of Suicide Research 4 (2): 135-41. https://doi.org/10.1080/13811119808260443.

Lynch, Kyan. 2020. “On Leaving Clinical Medicine." Annals of Internal Medicine 172 (7): 497. https://doi.org/10.7326/M19-2666.

Marvasti, Jamshid A., and Ali Vahidy. 2008. "How Healers Become Killers: Physicians as Suicide Bombers." American Journal of Forensic Psychaitry 29 (4): 39-55.

Meerten, Maja, Julia Bland, Samantha R. Gross, and Antony I. Garelick. 2011. “Doctors' Experience of a Bespoke Physician Consultation Service: Cross-Sectional Investigation." The Psychiatrist 35 (06): 206-12. https://doi.org/10.1192/ pb.bp.110.031047.

Moutier, Christine, William Norcross, Pam Jong, Marc Norman, Brittany Kirby, Tara McGuire, and Sidney Zisook. 2012. “The Suicide 
Prevention and Depression Awareness Program at the University of California, San Diego School of Medicine." Academic Medicine 87 (3): 320-26. https://doi.org/10.1097/ACM.0b013e31824451ad.

Neil, H. A.W., J. G. Fairer, M. P. Coleman, Amanda Thurston, and M. P. Vessey. 1987. "Mortality among Male Anaesthetists in the United Kingdom, 1957-83." BMJ 295 (6594): 360-62. https://doi. org/10.1136/bmj.295.6594.360.

Osama, Muhammad, Mohammad Yousuful Islam, Syed Ather Hussain, Syed Muhammad Zia Masroor, Muhammad Usman Burney, Muhammad Atif Masood, Ritesh G. Menezes, and Razaur Rehman. 2014. "Suicidal Ideation among Medical Students of Pakistan: A Cross-Sectional Study." Journal of Forensic and Legal Medicine 27: 65-68. https://doi.org/10.1016/j.jflm.2014.08.006.

Pepitone-Arreola-Rockwell, Fran, Don Rockwell, and Nolan Core. 1981. "Fifty-Two Medical Student Suicides." American Journal of Psychiatry 138 (2): 198-201. https://doi.org/10.1176/ajp.138.2.198.

Peters, Micah D.J., Christina M. Godfrey, Hanan Khalil, Patricia Mclnerney, Deborah Parker, and Cassia Baldini Soares. 2015. "Guidance for Conducting Systematic Scoping Reviews." International Journal of Evidence-Based Healthcare 13 (3): 14146. https://doi.org/10.1097/XEB.0000000000000050.

Peterson, Cora, Deborah M. Stone, Suzanne M. Marsh, Pamela K. Schumacher, Hope M. Tiesman, Wendy LiKamWa McIntosh, Colby N. Lokey, Aimée-Rika T. Trudeau, Brad Bartholow, and Feijun Luo. 2018. "Suicide Rates by Major Occupational Group - 17 States, 2012 and 2015." MMWR. Morbidity and Mortality Weekly Report 67 (45): 1253-60. https://doi.org/10.15585/mmwr.mm6745a1.

Poorman, Elisabeth. 2019. “Depression and Suicide: Occupational Hazards of Practicing Medicine." Journal of Patient Safety and Risk Management 24 (5): 181-83. https://doi. org/10.1177/2516043519866993.

Reger, Mark A., Ian H. Stanley, and Thomas E. Joiner. 2020. "Suicide Mortality and Coronavirus Disease 2019-A Perfect Storm?" JAMA Psychiatry 117 (2): 575-600. https://doi.org/10.1001/ jamapsychiatry.2020.1060.

Richings, J C, G S Khara, and M McDowell. 1986. "Suicide in Young Doctors." The British Journal of Psychiatry 149 (October): 475-78. http://www.ncbi.nlm.nih.gov/pubmed/3814932.

Rimpelä, Arja H., Pekka O. Pulkkinen, Markku M. Nurminen, Matti K. Rimpelä, and Tapani Valkonen. 1987. "Mortality of Doctors: Do Doctors Benefit From Their Medical Knowledge?" The Lancet 329 (8524): 84-86. https://doi.org/10.1016/S0140-6736(87)91919-2.
Rosta, Judith, and Olaf G. Aasland. 2013. "Changes in the Lifetime Prevalence of Suicidal Feelings and Thoughts among Norwegian Doctors from 2000 to 2010: A Longitudinal Study Based on National Samples." BMC Psychiatry 13 (1): 1-10. https://doi. org/10.1186/1471-244X-13-322.

Schernhammer, Eva S, and Graham A Colditz. 2004. "Suicide Rates among Physicians: A Quantitative and Gender Assessment (Meta-Analysis)." The American Journal of Psychiatry 161 (12): 2295-2302. https://doi.org/10.1176/appi.ajp.161.12.2295.

Shanafelt, Tait, Mickey Trockel, Jon Ripp, Mary Lou Murphy, Christy Sandborg, and Bryan Bohman. 2019. "Building a Program on WellBeing: Key Design Considerations to Meet the Unique Needs of Each Organization." Academic Medicine 94 (2): 156-61. https://doi. org/10.1097/ACM.0000000000002415.

Sun, Long, Chengchao Zhou, Lingzhong Xu, Shixue Li, Fanlei Kong, and Jie Chu. 2017. "Suicidal Ideation, Plans and Attempts among Medical College Students in China: The Effect of Their Parental Characteristics." Psychiatry Research 247 (April 2016): 139-43. https://doi.org/10.1016/j.psychres.2016.11.024.

Swanson, S. P., L. J. Roberts, and M. D. Chapman. 2003. “Are Anaesthetists Prone to Suicide? A Review of Rates and Risk Factors." Anaesthesia and Intensive Care 31 (4): 434-45. http:// www.ncbi.nlm.nih.gov/pubmed/12973968.

The Joanna Briggs Institute. 2015. "Joanna Briggs Institute Reviewers' Manual 2015: Methodology for JBI Scoping Reviews." Adelaide, South Australia. http://joannabriggs.org/assets/docs/ sumari/Reviewers-Manual_Methodology-for-JBI-ScopingReviews_2015_v2.pdf.

Thomas, Caroline Bedell, and Richard L. Greenstreet. 1973. "Psychobiological Characteristics in Youth as Predictors of Five Disease States: Suicide, Mental Illness, Hypertension, Coronary Heart Disease and Tumor." The Johns Hopkins Medical Journal 132 (1): 16-43.

Thomas, Jill C. 2014. "Re-Visioning Medicine." Journal of Medical Humanities 35 (4): 405-22. https://doi.org/10.1007/s10912-0149304-6.

Tyssen, Reidar, Erlend Hem, Per Vaglum, Nina T Grønvold, and Øivind Ekeberg. 2004. "The Process of Suicidal Planning among Medical Doctors: Predictors in a Longitudinal Norwegian Sample." Journal of Affective Disorders 80 (2-3): 191-98. https://doi. org/10.1016/S0165-0327(03)00091-0. 
Tyssen, Reidar, Per Vaglum, Nina T. Grønvold, and Øivind Ekeberg. 2001. “Suicidal Ideation among Medical Students and Young Physicians: A Nationwide and Prospective Study of Prevalence and Predictors." Journal of Affective Disorders 64 (1): 69-79. https:// doi.org/10.1016/S0165-0327(00)00205-6.

Ullmann, Daniel, Roland L. Phillipst, W. Lawrence Beeson, Houston G. Dewey, Burton N. Brin, Jan W. Kuzma, Chacko P. Mathews, and Albert E. Hirst. 1991. "Cause-Specific Mortality Among Physicians With Differing Life-Styles." JAMA: The Journal of the American Medical Association 265 (18): 2352-59. https://doi. org/10.1001/jama.1991.03460180058033.

Wang, Yu, Lei Liu, and Hongbin Xu. 2017. "Alarm Bells Ring: Suicide among Chinese Physicians." Medicine (United States) 96 (32): 96-98. https://doi.org/10.1097/MD.0000000000007790.

Williams, Lynne Sears. 1997. "Manitoba Suicides Force Consideration of Stresses Facing Medical Residents." CMAJ 156 (11): 1599-1602. http://www.ncbi.nlm.nih.gov/pubmed/9176428.

Worley, Linda L.M. 2008. "Our Fallen Peers: A Mandate for Change." Academic Psychiatry 32 (1): 8-12. https://doi.org/10.1176/appi. ap.32.1.8

Yasri, Sora, and Viroj Wiwanitkit. 2017. "Committing Suicide by Physicians: A Summary from Thai Situation." Annals of Tropical Medicine and Public Health 10 (2): 460-61. https://doi. org/10.4103/1755-6783.196833.

Young, James J., Robert J. Ursano, Ralph E. Bally, and Deanna S. McNeil. 1989. "Consultation to a Clinic Following Suicide." The American Journal of Orthopsychiatry 59 (3): 473-76. http://www. ncbi.nlm.nih.gov/pubmed/2764080.

Zisook, Sidney, Ilanit Young, Neal Doran, Nancy Downs, Allison Hadley, Brittany Kirby, Tara McGuire, Christine Moutier, William Norcross, and Maria Tiamson-Kassab. 2016. "Suicidal Ideation among Students and Physicians at a U.S. Medical School: A Healer Education, Assessment and Referral (HEAR) Program Report." Omega - Journal of Death and Dying 74 (1): 35-61. https://doi. org/10.1177/0030222815598045. 


\section{APPENDIX 1}

Ovid MEDLINE, PsycInfo, and Scopus Search Terms

\begin{tabular}{|c|c|c|}
\hline Date & Source & Query \\
\hline $8 / 21 / 2017$ & Investigators & $\mathrm{n} / \mathrm{a}$ \\
\hline 8/21/2017 & Ovid MEDLINE & $\begin{array}{l}\text { 1. (I (physician* or intern or interns or internship or fellow or resident* or residency or medical } \\
\text { student* or doctor* or 'medical student*') adj5 (\$suicid\$ or self } \$ \text { harm or self } \$ \text { injury)] not } \\
\text { (\$assisted or euthanasial).mp. [mp=title, abstract, original title, name of substance word, } \\
\text { subject heading word, keyword heading word, protocol supplementary concept word, rare } \\
\text { disease supplementary concept word, unique identifier, synonyms] } \\
\text { 2. exp Physicians/ } \\
\text { 3. Students, Medical/ } \\
\text { 4. exp Education, Medical/ } \\
\text { 5. } 2 \text { or } 3 \text { or } 4 \\
\text { 6. Suicide/ } \\
\text { 7. ( } 5 \text { and 6) not (\$assisted or euthanasia).mp. [mp=title, abstract, original title, name of } \\
\text { substance word, subject heading word, keyword heading word, protocol supplementary } \\
\text { concept word, rare disease supplementary concept word, unique identifier, synonyms] } \\
\text { 8. } 1 \text { or } 7\end{array}$ \\
\hline 10/11/2017 & PsyclNFO & $\begin{array}{l}\text { 1. (l(physician* or intern or interns or internship or fellow or resident* or residency or medical } \\
\text { student* or doctor* or 'medical student*') adj5 (\$suicid\$ or self\$harm or self\$injury)] not } \\
\text { (\$assisted or euthanasia)).mp. [mp=title, abstract, original title, name of substance word, } \\
\text { subject heading word, keyword heading word, protocol supplementary concept word, rare } \\
\text { disease supplementary concept word, unique identifier, synonyms] 2. exp Physicians/ } \\
\text { 3. Students, Medical/ 4. exp Education, Medical/ } 5.2 \text { or } 3 \text { or } 46 \text {. Suicide/ } 7 \text {. (5 and 6) not } \\
\text { (\$assisted or euthanasia).mp. [mp=title, abstract, original title, name of substance word, } \\
\text { subject heading word, keyword heading word, protocol supplementary concept word, rare } \\
\text { disease supplementary concept word, unique identifier, synonyms] } 8.1 \text { or } 7\end{array}$ \\
\hline $4 / 28 / 2018$ & Scopus & $\begin{array}{l}\text { ( TITLE-ABS-KEY ( medical AND student* ) OR TITLE-ABS-KEY ( physician* OR fellow OR } \\
\text { residency OR doctor* ) W/5 TITLE-ABS-KEY ( suicid* OR self-harm OR self-injury ) ) AND NOT ( } \\
\text { TITLE-ABS-KEY ( *assisted OR euthanasia OR nurs* OR patient* OR undergraduate* ) ) }\end{array}$ \\
\hline
\end{tabular}

\section{APPENDIX 2}

\section{Included Full-Text Articles for Review}

1. Aasland OG, Ekeberg $\varnothing$, Schweder T. Suicide rates from 1960 to 1989 in Norwegian physicians compared with other educational groups. Soc Sci Med. 2001 Jan;52(2):259-65.

2. Aasland OG, Hem E, Haldorsen T, Ekeberg Ø. Mortality among Norwegian doctors 1960-2000. BMC Public Health. 2011;11(1):173.

3. Aasland OG. Physician suicide-why? Gen Hosp Psychiatry. 2013;35(1):1-2.

4. Adams Greenup R. The Other Side of the Stethoscope. Acad Psychiatry. 2008 Feb 1;32(1):1-2.

5. Adler NR, Adler KA, Grant-Kels JM. Doctors' mental health, burnout, and suicidality: Professional and ethical issues in the workplace. J Am Acad Dermatol. 2017;77(6):1191-3.

6. Agerbo E, Gunnell D, Bonde JP, Bo Mortensen P, Nordentoft M. Suicide and occupation: the impact of socio-economic, demographic and psychiatric differences. Psychol Med. 2007 Aug 20;37(08):1131.

7. Ahmed SA, Omar QH, Abo Elamaim AA. Forensic analysis of suicidal ideation among medical students of Egypt: A crosssectional study. J Forensic Leg Med. 2016;44:1-4.

8. Alexandrino-Silva C, Pereira MLG, Bustamante C, Ferraz ACDT, Baldassin S, De Andrade AG, et al. Suicidal ideation among students enrolled in healthcare training programs: A cross-sectional study. Rev Bras Psiquiatr. 2009;31(4):338-44.

9. Allroggen M, Kleinrahm R, Rau TAD, Weninger L, Ludolph AG, Plener PL. Nonsuicidal Self-Injury and Its Relation to Personality Traits in Medical Students. J Nerv Ment Dis. 2014;202(4):300-4. 
10. Physician mortality and suicide. Results and implications of the AMA-APA Pilot Study. AMA Council on Scientific Affairs. Conn Med. 1986 Jan;50(1):37-43.

11. Amiri L, Voracek M, Yousef S, Galadari A, Yammahi S, Sadeghi MR, et al. Suicidal behavior and attitudes among medical students in the United Arab Emirates. Crisis. 2013;34(2):116-23.

12. Anders DL. Risky Business. JAMA. 1988;260(21):3184.

13. Anonymous. Suicides of physicians and the reasons. JAMA J Am Med Assoc. 1903 Jul 25;XLI(4):263.

14. Anonymous. Mental disturbance in doctors. Br Med J. 1969 Jan 16;4(5681):448.

15. Anonymous. Mentally Disturbed Doctors. Br Med J. 1972;(March 11):643.

16. Anteski M. Letters: Suicide by Physicians. JAMA. 1984;252(24):3364.

17. Arnetz BB, Hörte LG, Hedberg A, Theorell T, Allander E, Malker H. Suicide patterns among physicians related to other academics as well as to the general population. Acta Psychiatr Scand. 1987 Feb;75(2):139-43.

18. Austin AE, van den Heuvel C, Byard RW. Physician Suicide. J Forensic Sci. 2013 Jan;58(12):S91-3.

19. Ayala EE, Roseman D, Winseman JS, Mason HRC. Prevalence, perceptions, and consequences of substance use in medical students. Med Educ Online. 2017;22(1):1392824.

20. Balch CM, Shanafelt TD. Combating Stress and Burnout in Surgical Practice: A Review. Adv Surg. 2010 Sep;44(1):29-47.

21. Behera C, Swain R, Mridha AR anjan, Pooniya S. Suicide by injecting lispro insulin with an intravenous cannula. Med Leg J. 2015;83(3):147-9.

22. Bergman J. The Suicide Rate Among Psychiatrists Revisited. Suicide Life-Threatening Behav. 1979;9(4):219-26.

23. Best JA. The Things We Have Lost. JAMA. 2016 Nov 8;316(18):1871-2.

24. Birmingham PK, Ward RJ. A High-Risk Suicide Group: The Anesthesiologist Involved in Litigation. Am J Psychiatry. 1985;142(10):1225-6.

25. Bittker TE. Reaching out to the depressed physician. JAMA. 1976 Oct 11;236(15):1713-6.

26. Blachly P. Suicide in Physicians. JAMA. 1968;210(2):348.

27. Black D. When physicians commit suicide. Iowa Med. 1992;82(2):58-61.

28. Bock J, Burgdorf WHC, Hoenig LJ, Parish LC. The fate of Hungarian Jewish dermatologists during the Holocaust: Part 2: Under Nazi rule. Clin Dermatol. 2016;34(6):768-78.

29. Bondurant R, Morton N. Implementing Change to Reduce Depression, Suicide, and Burnout Among Physicians-in-Training. Mo Med. 2016;113(1):16-8.

30. Bourne T, Wynants L, Peters M, Van Audenhove C, Timmerman D, Van Calster B, et al. The impact of complaints procedures on the welfare, health and clinical practise of 7926 doctors in the UK: A cross-sectional survey. BMJ Open. 2015;5(1):1-12.

31. Brandt-Casadevall C, Krompecher T, Giroud C, Mangin P. A case of suicide disguised as natural death. Sci Justice - J Forensic Sci Soc. 2003;43(1):41-3.

32. Braquehais MD. Reconsidering suicide prevention strategies in physicians. Aust N Z J Psychiatry. 2011 Dec;45(12):1095-6.

33. Braquehais MD, Eiroa-Orosa FJ, Holmes KM, Lusilla P, Bravo M, Mozo X, et al. Differences in Physicians' and Nurses' Recent Suicide Attempts: An Exploratory Study. Arch Suicide Res. 2016;20(2):273-9.

34. Bressler B. Suicide and Drug Abuse in the Medical Community. Suicide Life-Threatening Behav. 1976;6(3):169-78.

35. Broquet KE. Teaching Residents and Program Directors About Physician Impairment. Acad Psychiatry. 2004 Sep 1;28(3):221-5.

36. Bruce DL, Eide KA, Linde HW, Eckenhoff JE. Causes of Death among Anesthesiologists: A 20-Year Survey. Anesthesiology. 1968;29(3):565-9.

37. Burrows GD. Stress and distress in middle age - The mental heath of doctors. Aust Fam Physician. 1976;5(October):1203-10.

38. Carlson GA, Miller DC. Suicide, Affective Disorder, and Women Physicians. Am J Psychiatry. 1981;138(10):1330-5.

39. Carpenter LM, Swerdlow AJ, Fear NT. Mortality of doctors in different specialties: Findings from a cohort of 20000 NHS hospital consultants. Occup Environ Med. 1997;54(6):388-95.

40. Carr GD. Physician Suicide - A Problem for Our Time. J MSMA. 2008;49(10):308-12.

41. Casey D, Choong KA. Suicide whilst under GMC's fitness to practise investigation: Were those deaths preventable? J Forensic Leg Med. 2016;37:22-7.

42. Cath SH. Some Human Factors in the Flying Physician. Aerosp Med. 1974;45(11):1298-302.

43. Center C, Davis M, Detre T, Ford DE, Hansbrough W, Hendin H, et al. Confronting Depression and Suicide in Physicians. JAMA. 2003;289(23):3161. 
44. Cheng J, Kumar S, Nelson E, Harris T, Coverdale J. A National Survey of Medical Student Suicides. Acad Psychiatry. 2014 Oct 25;38(5):542-6.

45. Clarke R, McKee M. Suicides among junior doctors in the NHS. BMJ. 2017;357:1-2.

46. Clements W, Paine R. The Family Physician’s Family. J Fam Pract. 1981;13(1):105-12.

47. Coentre R, Faravelli C, Figueira ML. Assessment of depression and suicidal behaviour among medical students in Portugal. Int J Med Educ. 2016;7:354-63.

48. Boxer PA, Burnett C, Swanson N. Suicide and Occupation: A Review of the Literature. J Occup Environ Med. 1995;37:442-52.

49. Cohen E. Suicide in Physicians. JAMA. 1972 Oct;222(4):489-90.

50. Cohen E. Suicide and self-assault: an introductory course for medical students. J Med Educ. 1974 Apr;49(4):383-5.

51. Cohen E. Suicide-Prone Physicians. JAMA J Am Med Assoc. 1972 Mar 27;219(13):1762.

52. Collier R. Physician suicide too often "brushed under the rug." CMAJ. 2017;189(39):E1240-1.

53. Colucci AP, Gagliano-Candela R, Aventaggiato L, De Donno A, Leonardi S, Strisciullo G, et al. Suicide by Self-Administration of a Drug Mixture (Propofol, Midazolam, and Zolpidem) in an Anesthesiologist: The First Case Report in Italy. J Forensic Sci. 2013;58(3):837-41.

54. Compton MT, Carrera J, Frank E. Stress and depressive symptoms/dysphoria among us medical students: Results from a large, nationally representative survey. J Nerv Ment Dis. 2008;196(12):891-7.

55. Coomber S, Todd C, Park G, Baxter P, Firth-Cozens J, Shore S. Stress in UK intensive care unit doctors. Br J Anaesth. 2002 Dec;89(6):873-81.

56. Cornette MM, Deroon-Cassini TA, Fosco GM, Holloway RL, Clark DC, Joiner TE. Application of an interpersonalpsychological model of suicidal behavior to physicians and medical trainees. Arch Suicide Res. 2009;13(1):1-14.

57. Craig AG, Pitts FN. Suicide by physicians. Dis Nerv Syst. 1968 Nov;29(11):763-72.

58. Crawford JP. Mental disturbance in doctors. Br Med J. 1971 Jan 16;1(5741):175.

59. Crawshaw R. Suicide by Physicians on Probation-Reply. JAMA J Am Med Assoc. 1981 Apr 17;245(15):1527.

60. Crawshaw R, Bruce JA, Eraker PL, Greenbaum M, Lindemann JE, Schmidt DE. An epidemic of suicide among physicians on probation. JAMA. 1980 May 16;243(19):1915-7.

61. Curran TA, Gawley E, Casey P, Gill M, Crumlish N. Depression, suicidality and alcohol abuse among medical and business students. Ir Med J. 2009;102(8):2007-8.

62. Daneault S. The wounded healer: can this idea be of use to family physicians? Can Fam Physician. 2008;54:1218-9.

63. Das S. The incidence of suicides among physicians and dentists: An unexplained story. Occup Med (Chic Ill). 2008;58(2):1501.

64. Daubs J. The mental health crisis in ophthalmology. Am J Optom Arch Am Acad Optom. 1973 Oct;50(10):816-22.

65. De Hart C. Suicide by Physicians. JAMA. 1974;65(2):32-3.

66. de la Monte SM, Hutchins GM. Is suicide a special occupational hazard for physicians? JAMA. 1984;251(15):1952-3.

67. De Rosis H. Editorial: Suicide among psychiatrists. Am J Psychoanal. 1974;34(2):97-8.

68. Dempsey JJ. Physician Suicide. JAMA J Am Med Assoc. 1987 Sep 25;258(12):1607.

69. Derksen DJ. Dolores. Health Aff. 2002;21(5):218-23.

70. Desjardins M. Physician suicide. Can something be done? Can Fam Physician. 1997 Nov;43:1900-1, 1907-9.

71. DeSole DE, Singer P, Aronson S. Suicide and Role Strain Among Physicians. Int J Soc Psychiatry. 1969;15(4):294-301.

72. Devi S. Doctors in distress. Lancet. 2011;377(9764):454-5.

73. Dippo J. A Mother’s Story. Minn Med. 2007;(December):28-31.

74. Dobson R. Stresses on women doctors may cause higher suicide risk. BMJ. 2001;322(21):945.

75. Domino G, Takahashi Y. Attitudes toward suicide in Japanese and American medical students. Suicide Life Threat Behav. 1991;21(4):345-59.

76. Downs N, Feng W, Kirby B, McGuire T, Moutier C, Norcross W, et al. Listening to Depression and Suicide Risk in Medical Students: the Healer Education Assessment and Referral (HEAR) Program. Acad Psychiatry. 2014 Oct 5;38(5):547-53.

77. Duffy JC. The emotional health of physicians. Ann Intern Med. 1968;69(6):1319-22.

78. Duffy JC. Editorial: Suicides by Physicians in Training. J Med Educ. 1968;43(11):1196.

79. Dunn LB. Incidence of Suicides Among Physicians. JAMA J Am Med Assoc. 1965 Dec 13;194(11):1257.

80. Dwyer AJ, Morley P, Reid E, Angelatos C. Distressed doctors: A hospital-based support program for poorly performing and “at-risk" junior medical staff. Med J Aust. 2011:194(9):466-9. 
81. Dyrbye LN, Thomas MR, Massie FS, Power D V, Eacker A, Harper W, et al. Burnout and suicidal ideation among U.S. medical students. Ann Intern Med. 2008 Sep 2;149(5):334-41.

82. Dyrbye LN. Letters to the Editor: Medical Students and Depression. Acad Med. 2009;84(8):976.

83. Dyrbye LN, Power D V., Stanford Massie F, Eacker A, Harper W, Thomas MR, et al. Factors associated with resilience to and recovery from burnout: A prospective, multi-institutional study of US medical students. Med Educ. 2010;44(10):1016-26.

84. Dyrbye LN, Schwartz A, Downing SM, Szydlo DW, Sloan JA, Shanafelt TD. Efficacy of a brief screening tool to identify medical students in distress. Acad Med. 2011;86(7):907-14.

85. Dyrbye LN, Harper W, Durning SJ, Moutier C, Thomas MR, Massie FS, et al. Patterns of distress in US medical students. Med Teach. 2011;33(10):834-9.

86. Dyrbye LN, Satele D, Sloan J, Shanafelt TD. Utility of a Brief Screening Tool to Identify Physicians in Distress. J Gen Intern Med. 2013;28(3):421-7.

87. Dyrbye LN, West CP, Satele D, Boone S, Tan L, Sloan J, et al. Burnout among u.s. medical students, residents, and early career physicians relative to the general u.s. population. Acad Med. 2014;89(3):443-51.

88. Earle L, Kelly L. Coping strategies, depression, and anxiety among Ontario family medicine residents. Can Fam physician Médecin Fam Can. 2005;51(2):242-3.

89. Eckleberry-Hunt J, Lick D. Physician Depression and Suicide: A Shared Responsibility. Teach Learn Med. 2015;27(3):341-5.

90. Edirisinghe PAS, Busuttil A. Medical suicide - Groin stabbing. J Clin Forensic Med. 2006;13(2):92-5.

91. Eilers GM. Physician suicide. Arch Fam Med. 1996;5(4):197-8.

92. Ellard J. The disease of being a doctor. Med J Aust. 1974 Aug 31;2(9):318-23.

93. Eneroth M, Gustafsson Sendén M, Løvseth LT, Schenck-Gustafsson K, Fridner A. A comparison of risk and protective factors related to suicide ideation among residents and specialists in academic medicine. BMC Public Health. 2014;14(1):1-9.

94. Ennis J, Barnes R. More on suicide and women physicians. Am J Psychiatry. 1980;137(9):1125-6.

95. Epstein L, Thomas C, Shaffer J, Perlin S. Clinical prediction of physician suicide based on medical student data. Vol. 156, The Journal of Nervous and Mental Disease. 1973. p. 19-29.

96. Eskin M, Voracek M, Stieger S, Altinyazar V. A cross-cultural investigation of suicidal behavior and attitudes in Austrian and Turkish medical students. Soc Psychiatry Psychiatr Epidemiol. 2011;46(9):813-23.

97. Essex C. Doctor's suicide prompts look at hours. Br Med J. 1994;309(6961):1037.

98. Everson RB, Fraunteni JF. Mortality Among Medical Students and Young Physicians. J Med Educ. 1975;50:809-11.

99. Ey S, Moffit M, Kinzie JM, Brunett PH. Feasibility of a Comprehensive Wellness and Suicide Prevention Program: A Decade of Caring for Physicians in Training and Practice. J Grad Med Educ. 2016;8(5):747-53.

100. Familoni OB. An overview of stress in medical practice in Nigeria. Niger Hosp Pract. 2009 Jan 30;2(5):6-7.

101. Fan APC, Kosik RO, Su TP, Lee FY, Hou MC, Chen YA, et al. Letters to the Editor: Factors associated with suicidal ideation in Taiwanese medical students. Med Teach. 2011;33(3):256-7.

102. Fan APC, Kosik RO, Mandell G a, Tran DT, Cheng HM, Chen CH, et al. Suicidal ideation in medical students: who is at risk? Ann Acad Med Singapore. 2012;41(9):377-82.

103. Feeney S, O’Brien K, O'Keeffe N, Iomaire ANC, Kelly ME, McCormack J, et al. Practise what you preach: Health behaviours and stress among non-consultant hospital doctors. Clin Med J R Coll Physicians London. 2016;16(1):12-8.

104. Feola A, Cassandro P, Carfora A, Petrella R, Giordano C, Stefanizzi IM, et al. Suicides in physicians: Two cases of poisoning involving fentanyl and phenobarbital. Minerva Psichiatr. 2017;58(2):103-9.

105. Fernando GC. A suicide by thiopentone infusion. Am J Forensic Med Pathol. 1990 Dec;11(4):309-11.

106. Fink-Miller EL. An Examination of the Interpersonal Psychological Theory of Suicidal Behavior in Physicians. Suicide LifeThreatening Behav. 2015;45(4):488-94.

107. Fink-Miller EL. Provocative work experiences predict the acquired capability for suicide in physicians. Psychiatry Res. 2015;229(1-2):143-7.

108. Fink-Miller EL, Nestler LM. Suicide in physicians and veterinarians: risk factors and theories. Curr Opin Psychol. 2018;22:236.

109. Finlayson AJR, Iannelli RJ, Brown KP, Neufeld RE, DuPont RL, Campbell MD. Re: Physician suicide and physician health programs. Gen Hosp Psychiatry. 2016;40:84-5.

110. Finseth K. Suicide Among Women Physicians. JAMA. 1977;237(16):1693.

111. Fitzgerald F, Murray TJ. On the death of house officers. Ann Intern Med. 1998 Jun 1;128(11):949-50. 
112. Frank E, Dingle AD. Self-reported depression and suicide attempts among U.S. women physicians. Am J Psychiatry. 1999 Dec;156(12):1887-94.

113. Freed H. Occupational hazards to physicians--suicide. Pa Med. 1969 Oct;72(10):65-6.

114. Fridner A, Belkic K, Marini M, Minucci D, Pavan L, Schenck-Gustafsson K. Survey on recent suicidal ideation among female university hospital physicians in Sweden and Italy (the HOUPE study): Cross-sectional associations with work stressors. Gend Med. 2009;6(1):314-28.

115. Fridner A, Belkić K, Minucci D, Pavan L, Marini M, Pingel B, et al. Work environment and recent suicidal thoughts among male university hospital physicians in Sweden and Italy: The Health and Organization among University Hospital Physicians in Europe (HOUPE) study. Gend Med. 2011;8(4):269-79.

116. Fridner A, Belkić K, Marini M, Sendén MG, Schenck-Gustafsson K. Why don’t academic physicians seek needed professional help for psychological distress? Swiss Med Wkly. 2012;142(JULY):1-8.

117. Gold MS, Frost-Pineda K, Melker RJ. Letters to the Editor: Physician suicide and drug abuse. Am J Psychiatry. 2005;162(7):1390; author reply 1390.

118. Goldman ML, Shah RN, Bernstein CA. Addressing Depression and Suicide Among Physician Trainees--Reply. JAMA psychiatry. 2015 Aug;72(8):848-9.

119. Goldman ML, Shah RN, Bernstein CA. Depression and suicide among physician trainees: Recommendations for a national response. JAMA Psychiatry. 2015;72(5):411-2.

120. Graves PL, Thomas CB. Habits of Nervous Tension and Suicide. Suicide Life-Threatening Behav. 1991;21(2):91-105.

121. Gagné P, Moamai J, Bourget D. Psychopathology and suicide among quebec physicians: A nested case control study. Depress Res Treat. 2011;2011:936327.

122. Genovese JM, Berek JS. Can Arts and Communication Programs Improve Physician Wellness and Mitigate Physician Suicide? J Clin Oncol. 2016;34(15):1820-2.

123. Gerada C. Doctors and suicide. Br J Gen Pract. 2018;68(669):168-9.

124. Gerkin DG. Struggling in Silence: physician suicide. Tenn Med. 2013;106(2):7-8.

125. Ghazanfar H, Hameed S, Ghazanfar A, Bhatti JRA, Haq I ul, Saeed R, et al. Suicidal ideation among Pakistani medical students. Rawal Med J. 2015;40(4):458-62.

126. Gojdź K, Bąk-Sosnowska M, Kołodziej S, Skrzypulec-Plinta V. Quality of life of female physicians aged 45-55 years. Prz Menopauzalny. 2013;17(3):213-5.

127. Gold KJ, Sen A, Schwenk TL. Details on suicide among US physicians: data from the National Violent Death Reporting System. Gen Hosp Psychiatry. 2013 Jan;35(1):45-9.

128. Gold KJ, Sen A, Schwenk TL. Authors' response to letter to the editor "Details on suicide among US physicians: Data from the National Violent Death Reporting System." Gen Hosp Psychiatry. 2013;35(4):449.

129. Gray RW. Physician suicide rates show alarming need for education. Tenn Med. 2009 Jul;102(7):39.

130. Gray RW. Physician suicide rates show Alarming Need for education. Tenn Med. 2013;106(10):27.

131. Grocott HP, Bryson GL. The physician at risk: disruptive behaviour, burnout, addiction, and suicide. Can J Anesth Can d’anesthésie. 2017;64(2):119-21.

132. Guclu M, Ersoy C, Imamoglu S. Suicide attempt of a physician with 3600 units of insulin and rapid onset acute hepatitis. Intern Med J. 2009 Dec;39(12):e5-7.

133. Guille C, Zhao Z, Krystal J, Nichols B, Brady K, Sen S. Web-based cognitive behavioral therapy intervention for the prevention of suicidal ideation in medical interns a randomized clinical trial. JAMA Psychiatry. 2015;72(12):1192-8.

134. Gyorffy Z, Girasek E. Mental Health of Physicians -- Nationwide Representative Study from Hungary. Ideggyogy Sz. 2015;68(7-8):258-69.

135. Gyorffy Z, Dweik D, Girasek E. Workload, mental health and burnout indicators among female physicians. Hum Resour Health. 2016;14(1):1-10.

136. Hampton T. Experts address risk of physician suicide. J Am Med Assoc. 2005;294(10):1189-91.

137. Haskins J, Carson JG, Chang CH, Kirshnit C, Link DP, Navarra L, et al. The Suicide Prevention, Depression Awareness, and Clinical Engagement Program for Faculty and Residents at the University of California, Davis Health System. Acad Psychiatry. 2016 Feb 11;40(1):23-9.

138. Hawton K, Clements A, Simkin S, Malmberg A. Doctors who kill themselves: a study of the methods used for suicide. QJM. 2000 Jun;93(6):351-7. 
139. Hawton K, Clements A, Sakarovitch C, Simkin S, Deeks JJ. Suicide in Doctors: a Study of Risk according to Gender, Seniority and Speciality in Medical Practicioners in England and Wales. J Epidemiol Community Heal. 2001;55(5):296-300.

140. Hawton K, Malmberg A, Simkin S. Suicide in doctors: A psychological autopsy study. J Psychosom Res. 2004;57(1):1-4.

141. Hawton K, Agerbo E, Simkin S, Platt B, Mellanby RJ. Risk of suicide in medical and related occupational groups: A national study based on Danish case population-based registers. J Affect Disord. 2011;134(1-3):320-6.

142. Hawton K. Suicide in doctors while under fitness to practise investigation. BMJ. 2015;350(February):1-2.

143. Hayashi T, Buschmann C, Riesselmann B, Roscher S, Tsokos M. Circumstantial and toxicological features of deaths from self-administered intravenous anesthetic/narcotic agents. Forensic Sci Med Pathol. 2013;9(2):138-44.

144. Hays LR, Cheever T, Patel P. Medical Student Suicide, 1989-1994. Am J Psychiatry. 1996;153:553-5.

145. Helliwell PJ. Suicide amongst anaesthetists-in-training. Anaesthesia. 1983 Nov;38(11):1097.

146. Hochberg MS, Berman RS, Kalet AL, Zabar SR, Gillespie C, Pachter HL. The stress of residency: Recognizing the signs of depression and suicide in you and your fellow residents. Am J Surg. 2013;205(2):141-6.

147. Hubbard SD. Suicide Among Physicians. Am J Public Health. 1922;12(10):857.

148. Hubbeling D. Letters to the Editor: Medical students and depression. Acad Med. 2009;84(8):976.

149. Hussey HH. Editorial: Suicide among physicians. JAMA. 1974 May 27;228(9):1149-50.

150. Hem E, Grønvold NT, Aasland OG, Ekeberg $\varnothing$. The prevalence of suicidal ideation and suicidal attempts among Norwegian physicians. Results from a cross-sectional survey of a nationwide sample. Eur Psychiatry. 2000 May;15(3):183-9.

151. Hem E, Aasland OG, Ekeberg Ø. Are anaesthetists prone to suicide? A review of rates and risk factors. Anaesth Intensive Care. 2004 Apr;32(2):288-9; author reply 289-90.

152. Hem E, Haldorsen T, Aasland OG, Tyssen R, Vaglum P, Ekeberg Ø. Suicide among physicians. Am J Psychiatry. 2005;162(11):2199-200.

153. Hem E, Haldorsen T, Aasland OG, Tyssen R, Vaglum P, Ekeberg Ø. Suicide rates according to education with a particular focus on physicians in Norway 1960-2000. Psychol Med. 2005;35(6):873-80.

154. Hendin H, Maltsberger JT, Pollinger Haas A. Clinical Case Conference A Physician's Suicide. Am J Psychiatry. 2003;160(12):2094-7.

155. Hendin H, Maltsberger JT, Haas AP. “A physician’s suicide”: Reply. Am J Psychiatry. 2004;161(12):2330-1.

156. Hikiji W, Fukunaga T. Suicide of physicians in the special wards of Tokyo Metropolitan area. J Forensic Leg Med. 2014 Feb;22:37-40.

157. Hiyama T, Yoshihara M. New occupational threats to Japanese physicians: karoshi (death due to overwork) and karojisatsu (suicide due to overwork). Occup Environ Med. 2008 Jun;65(6):428-9.

158. Iannelli RJ, Finlayson AJR, Brown KP, Neufeld R, Gray R, Dietrich MS, et al. Suicidal behavior among physicians referred for fitness-for-duty evaluation. Gen Hosp Psychiatry. 2014;36(6):732-6.

159. IsHak W, Nikravesh R, Lederer S, Perry R, Ogunyemi D, Bernstein C. Burnout in medical students: a systematic review. Clin Teach. 2013 Aug;10(4):242-5.

160. Issam E-R, Fadia H, Viviane C, Christine D. Suicidal behavior among medical students. Med Teach. 2009 Jan 3;31(3):315-6.

161. Jackson ER, Shanafelt TD, Hasan O, Satele D V., Dyrbye LN. Burnout and alcohol abuse/dependence among U.S. Medical Students. Acad Med. 2016;91(9):1251-6.

162. Jeon HJ, Roh MS, Kim KH, Lee JR, Lee D, Yoon SC, et al. Early trauma and lifetime suicidal behavior in a nationwide sample of Korean medical students. J Affect Disord. 2009;119(1-3):210-4.

163. Jha MK, Mazumder A, Garg A. Suicide by medical students - A disturbing trend. J Punjab Acad Forensic Med Toxicol. 2014;14(1):40-2.

164. Johnson WDK. Predisposition to emotional distress and psychiatric illness amongst doctors: The role of unconscious and experiential factors. Br J Med Psychol. 1991;64(4):317-29.

165. Johnston C. Suicide totals for MDs sad reminder of stresses facing medicine, conference told. Cmaj. 1996;155(1):109-11.

166. Johnston GP. Dangers of Self-Prescription. J Indiana State Med Assoc. 1979;72(8):570-2.

167. Jones RE. A study of 100 physician psychiatric inpatients. Am J Psychiatry. 1977 Oct;134(10):1119-23.

168. Juel K, Mosbech J, Hansen ES. Mortality and causes of death among Danish medical doctors 1973-1992. Int J Epidemiol. 1999;28(3):456-60.

169. Kaltreider NB. The impact of a medical student's suicide. Suicide Life Threat Behav. 1990;20(3):195-205. 
170. Khan R, Lin JS, Mata DA. Letter to the Editor: Addressing Depression and Suicide Among Physician Trainees. JAMA psychiatry. 2015 Aug;72(8):848.

171. Kirsling RA, Kochar MS. Suicide and the Stress of Residency Training: A Case Report and Review of the Literature. Psychol Rep. 1989 Jun;64(3):951-9.

172. Kitchen LW. Suicide among medical students. West J Med. 1978;45(3):145-9.

173. Koekkoek B, Gunderson JG, Kaasenbrood A, Gutheil TG. Chronic suicidality in a physician: An alliance yet to become therapeutic. Harv Rev Psychiatry. 2008;16(3):195-204.

174. Kõlves K, De Leo D. Suicide in medical doctors and nurses: An analysis of the Queensland suicide register. J Nerv Ment Dis. 2013;201(11):987-90.

175. Krakowski AJ. Stress and the practice of medicine- The myth and reality. J Psychosom Res. 1982;26(1):91-8.

176. Kuhn CM, Flanagan EM. Self-care as a professional imperative: physician burnout, depression, and suicide. Can J Anesth. 2017;64(2):158-68.

177. Ladouceur R. Distress among residents. Can Fam Physician. 2015;61(2):105-6.

178. Lederer W. Job conflicts and suicide among physicians. Eur Psychiatry. 2010;25(7):435.

179. Lees C. The gmc and doctors' suicides. BMJ. 2014;349(December):7740.

180. Legato MJ. Physician suicide: Unnecessary losses. Gend Med. 2009;6(1):247-8.

181. Legha RK. A History of Physician Suicide in America. J Med Humanit. 2012;33(4):219-44.

182. Lieberman EJ, Wolin SJ. Letters to the editor. Am J Surg. 1992 Feb;163(2):273-4.

183. Likeman RK. Physician, heal thyself. Med J Aust. 2015 Apr 20;202(7):383.

184. Lim M. Physician Depression and Suicide. Virtual Mentor. 2003;5(9):1-3.

185. Linde HW, Mesnick PS, Smith NJ. Causes of death among anesthesiologists: 1930-1946. Anesth Analg. 1981 Jan;60(1):1-7.

186. Lindeman S, Läärä E, Hakko H, Lönnqvist J. A Systematic Review on Gender-Specific Suicide Mortality in Medical Doctors. Br J Psychiatry. 1996 Mar 2;168(03):274-9.

187. Lindeman S, Läärä E, HIRVONEN J, Lönnqvist J. Suicide mortality among medical doctors in Finland: are females more prone to suicide than their male colleagues? Psychol Med. 1997 Sep;27(5):S0033291796004680.

188. Lindeman S, Läärä E, Lönnqvist J. Medical surveillance often precedes suicide among female physicians in Finland: A casecontrol study. J Occup Environ Med. 1997;39(11):1115-7.

189. Lindeman S, Läärä E, Vuori E, Lönnqvist J. Suicides among physicians, engineers and teachers: The prevalence of reported depression, admissions to hospital and contributory causes of death. Acta Psychiatr Scand. 1997;96(1):68-71.

190. Lindeman S, Heinänen H, Väisänen E, Lönnqvist J. Suicide among medical doctors: Psychological autopsy data on seven cases. Arch Suicide Res. 1998;4(2):135-41.

191. Lindeman S, Henriksson M, Isometsä E, Lönnqvist J. Treatment of mental disorders in seven physicians committing suicide. Crisis. 1999;20(2):86-9.

192. Lindfors PM, Meretoja OA, Luukkonen RA, Elovainio MJ, Leino TJ. Suicidality among Finnish anaesthesiologists. Acta Anaesthesiol Scand. 2009 Sep;53(8):1027-35.

193. Lipkin M. When Suicide Happens in the Medical Community. J Gen Intern Med. 2018 Nov 13 [cited 2019 Jan 30];1-3.

194. Lister J. Selection of Medical Students -- Occupational Mortality. N Engl J Med. 1987;298(21):1182-4.

195. Loas G, Lefebvre G, Rotsaert M, Englert Y. Relationships between anhedonia, suicidal ideation and suicide attempts in a large sample of physicians. PLoS One. 2018;13(3):1-23.

196. Mahmood K. Time to Act - Alarming Rise in Suicides Among Medical Professionals in Pakistan. J Coll Physicians Surg Pakistan. 2016 Dec;26(12):947-9.

197. Manning CL, Peters D, Lewith G. Doctors' suicides: Economic considerations and beyond. BMJ. 2015;350(March):2015.

198. Marchand WR, Palmer CA, Gutmann L BW 3rd. Medical student impairment: a review of the literature. W V Med J. 1985;81(11):244-8.

199. Marcus DC. Suicide by Physicians. JAMA. 1974;229(2):141.

200. Margolis PM. M.D. suicides. Why? Mich Med. 1968;67(9):589.

201. Martinac M, Sakić M, Skobić H, Jakovljević M. Suicidal ideation and medical profession: from medical students to hospital physicians. Psychiatr Danub. 2003 Dec;15(3-4):185-8.

202. Marvasti JA, Vahidy A. How Healers Become Killers: Physicians as Suicide Bombers. Am J Forensic Psychaitry. 2008;29(4):3955. 
203. McCabe S. Where have we gone wrong? Br J Gen Pract. 2013 Jan;63(606):35.

204. McCarron P, Okasha M, McEwen J, Davey Smith G. Association between course of study at university and cause-specific mortality. J R Soc Med. 2003;96(8):384-8.

205. McFarlane J. Suicide Junkie - poems by doctors. Br J Psychiatry. 2016;209(5):392.

206. McGuire T, Moutier C, Downs N, Zisook S. In response to "Details on suicide among US physicians: Data from the National Violent Death Reporting System.” Gen Hosp Psychiatry. 2013;35(4):448.

207. McManus IC. Increased mortality in women doctors. Lancet. 1995;345(8952):796-7.

208. Meerten M, Bland J, Gross SR, Garelick AI. Doctors' experience of a bespoke physician consultation service: cross-sectional investigation. Psychiatrist. 2011;35(06):206-12.

209. Melamed Y. Letter to the Editor: A Colleague’s Suicide. Am J Psychiatry. 1999;156(9):1472.

210. Menezes RG, Subba SH, Sathian B, Kharoshah MA, Senthilkumaran S, Pant S, et al. Suicidal ideation among students of a medical college in Western Nepal: A cross-sectional study. Leg Med. 2012;14(4):183-7.

211. Merlo LJ, Curran JS, Watson R. Gender differences in substance use and psychiatric distress among medical students: A comprehensive statewide evaluation. Subst Abus. 2017;38(4):401-6.

212. Middleton JL. Today I’m grieving a physician suicide. Ann Fam Med. 2008;6(3):267-9.

213. Miletic V, Lukovic JA, Ratkovic N, Aleksic D, Grgurevic A. Demographic risk factors for suicide and depression among Serbian medical school students. Soc Psychiatry Psychiatr Epidemiol. 2015;50(4):633-8.

214. Miller MN, McGowen KR. The painful truth: physicians are not invincible. South Med J. 2000 Oct;93(10):966-73.

215. Morrison L, Gillies J. Dr Pat Manson and the way forward. Br J Gen Pract. 2012;62(604):603-603.

216. Mount BM. Dealing with our losses. J Clin Oncol. 1986;4(7):1127-34.

217. Moutier C, Norcross W, Jong P, Norman M, Kirby B, McGuire T, et al. The Suicide Prevention and Depression Awareness Program at the University of California, San Diego School of Medicine. Acad Med. 2012 Mar;87(3):320-6.

218. Muller D. Kathryn. N Engl J Med. 2017 Mar 23;376(12):1101-3.

219. Murphy GE. Suicide by physicians on probation. JAMA. 1981 Apr 17;245(15):1526-7.

220. Murphy JFA. The vulnerability of doctors. Ir Med J. 2005;98(7):196.

221. Murray RM. Psychiatric Illness in Doctors. Lancet. 1974;303(7868):1211-3.

222. Murray RM. Characteristics and prognosis of alcoholic doctors. Br Med J. 1976;2(December):1537-9.

223. Murray RM. The health of doctors: a review. J R Coll Physicians Lond. 1978 Oct;12(5):403-15.

224. Naidech A. The death of house officers. Ann Intern Med. 1999 Jan 5;130(1):81.

225. Neil HAW, Fairer JG, Coleman MP, Thurston A, Vessey MP. Mortality among male anaesthetists in the United Kingdom, 1957-83. BMJ. 1987 Aug 8;295(6594):360-2.

226. Nichols GP. Adams offered us excellent advice. Wis Med J. 1992;91(9):521-5.

227. Nogueira-Martins LA, Stella RC, Nogueira HE. A pioneering experience in Brazil: the creation of a center for assistance and research for medical residents (NAPREME) at the Escola Paulista de Medicina, Federal University of São Paulo. Sao Paulo Med J. 1997;115(6):1570-4.

228. North CS, Ryall J-EM. Psychiatric illness in female physicians. Are high rates of depression an occupational hazard? Postgrad Med. 1997;101(5):240,242.

229. Okasha A, Lotaif F, Sadek A. Prevalence of suicidal feelings in a sample of non-consulting medical students. Acta Psychiatr Scand. 1981;63(5):409-15.

230. Olkinuora M, Asp S, Juntunen J, Kauttu K, Strid L, Aärimaa M. Stress symptoms, burnout and suicidal thoughts of Finnish physicians. Scand J Work Environ Health. 1992 Feb;18 Suppl 2(2):110-2.

231. Osama M, Islam MY, Hussain SA, Masroor SMZ, Burney MU, Masood MA, et al. Suicidal ideation among medical students of Pakistan: A cross-sectional study. J Forensic Leg Med. 2014;27:65-8.

232. Osmond H. Suicide, medicine and psychoanalysis. Ala J Med Sci. 1975;12(4):394-5.

233. Pan Y-JJ, Lee M-BB, Lin C-SS. Physician suicide in Taiwan, 2000-2008: preliminary findings. J Formos Med Assoc. 2009 Apr;108(4):328-32.

234. Patz JA, Jodrey D. Occupational Health in Surgery: Risks Extend Beyond the Operating Room. Aust N Z J Surg. 1995;65(9):627-9.

235. Pepitone-Arreola-Rockwell F, Rockwell D, Core N. Fifty-two medical student suicides. Am J Psychiatry. 1981 Feb;138(2):198201.

236. Prather E. Ultimate failure. Tex Med. 2005 May;101(5):30-8. 
237. Petersen MR, Burnett CA. The suicide mortality of working physicians and dentists. Occup Med (Chic Ill). 2008;58(1):25-9.

238. Petry JJ. Physician suicide. Plast Reconstr Surg. 2002 May;109(6):2171; author reply 2171.

239. Pitts FN, Schuller AB, Rich CL, Pitts AF. Suicide among U.S. women physicians, 1967-1972. Am J Psychiatry. 1979 May;136(5):694-6.

240. Plutzer MD. Family Therapy and a Physician’s Suicide. Am J Psychiatry. 2003;161(2):2328-9.

241. Pompili M, Mancinelli I, Girardi P, Tatarelli R. Letter to the Editor: On female physicians committing suicide. MedGenMed Medscape Gen Med. 2004;6(2):60.

242. Pompili M, Innamorati M, Narciso V, Kotzalidis GD, Dominici G, Talamo A, et al. Burnout, hopelessness and suicide risk in medical doctors. Clin Ter. 2010;161(6):511-4.

243. Pond DA. Doctors' mental health. N Z Med J. 1969;69(442):131-5.

244. Povar GJ, Belz M. Helping Ourselves. J Med Educ. 1980;55:632-4.

245. Preven DW. Physician suicide. Hillside J cCinical Psychiatry. 1981;3(1):61-70.

246. Pruthi S, Gupta V, Goel A. Medical students hanging by a thread. Educ Heal Chang Learn Pract. 2015;28(2):150-1.

247. Puthran R, Zhang MWB, Tam WW, Ho RC. Prevalence of depression amongst medical students: a meta-analysis. Med Educ. 2016;50(4):456-68.

248. Raeisei A, Mojahed A, Bakhshani N-M. The Relationship between Personality Styles of Sociotropy and Autonomy and Suicidal Tendency in Medical Students. Glob J Health Sci. 2015;7(3):345-50.

249. Rakatansky H. Letter to the Editor: Physician Suicide. N Engl J Med. 2005;353(11):1185-1185.

250. Rakatansky H. Physicians at high risk for suicide in US; incidence higher in women doctors. R I Med J. 2016;99(11):11-2.

251. Renshaw DC. Physician heal thyself. Aust Fam Physician. 1977 Jun;6(6):598-602.

252. Revicki DA, May HJ. Physician suicide in North Carolina. South Med J. 1985 Oct;78(10):1205-7.

253. Reynolds CF, Clayton PJ. Commentary: Out of the silence: Confronting depression in medical students and residents. Acad Med. 2009;84(2):159-60.

254. Reynolds CF. Preventing Suicidal Ideation in Medical Interns. JAMA psychiatry. 2015 Dec;72(12):1169-70.

255. Rich CL, Pitts FN. Suicide by male physicians during a five-year period. Am J Psychiatry. 1979;136(8):1089-90.

256. Richings JC, Khara GS, McDowell M. Suicide in young doctors. Br J Psychiatry. 1986 Oct;149:475-8.

257. Rimmer A. GMC urges national support service for doctors' health concerns. BMJ. 2014;349(December):g7777.

258. Rimpelä AH, Pulkkinen PO, Nurminen MM, Rimpelä MK, Valkonen T. Mortality of Doctors: Do Doctors Benefit From Their Medical Knowledge? Lancet. 1987;329(8524):84-6.

259. Rimpelä AH. Death amongst doctors. Stress Med. 1989;5(1989):73-5.

260. Rao NG, Menezes RG, Nagesh KR, Kamath GS. Suicide by combined insulin and glipizide overdose in a non-insulin dependent diabetes mellitus physician: a case report. Med Sci Law. 2006 Jul;46(3):263-9.

261. Robinson A, Sullivan P. The death of a doctor. Can Med Assoc J. 1993 Jun 1;148(11):1994-7.

262. Rockwell DA. Physicians' Knowledge and Attitudes About Suicide. JAMA J Am Med Assoc. 1973;225(11):1347.

263. Rockwell DA. Suicide in Physicians. West J Med. 1975;122(5):419-20.

264. Rosiek A, Rosiek-Kryszewska A, Leksowski Ł, Leksowski K. Chronic stress and suicidal thinking among medical students. Int J Environ Res Public Health. 2016;13(2).

265. Ross M. Suicide among physicians. Psychiatry Med. 1971 Jul;2(3):189-98.

266. Ross M. Suicide among physicians. A psychological study. Dis Nerv Syst. 1973 Mar;34(3):145-50.

267. Ross M. Physician suicide risk: practical recognition and management. South Med J. 1975 Jun;68(6):699-702.

268. Rosta J, Aasland OG. Changes in the lifetime prevalence of suicidal feelings and thoughts among Norwegian doctors from 2000 to 2010: A longitudinal study based on national samples. BMC Psychiatry. 2013;13(1):1-10.

269. Rotenstein LS, Ramos MA, Torre M, Segal JB, Peluso MJ, Guille C, et al. Prevalence of Depression, Depressive Symptoms, and Suicidal Ideation Among Medical Students. JAMA. 2016 Dec 6;316(21):2214.

270. Rothblum ED. Depression among women in medicine. Conn Med. 1981 Aug;45(8):501-3.

271. Sansone RA, Sansone LA. Physician suicide: a fleeting moment of despair. Psychiatry (Edgmont). 2009;6(1):18-22.

272. Rubin R. Recent suicides highlight need to address depression in medical students and residents. JAMA. 2014;312(17):1725-7.

273. Russell AT, Pasnau RO, Taintor ZC. Emotional problems of residents in psychiatry. Am J Psychiatry. 1975 Mar;132(3):263-7.

274. Sakinofsky I. Suicide In Doctors and Wives of Doctors. Can Fam Physician. 1980;26:837-44.

275. Sakinofsky I. Suicide in doctors and their wives. Br Med J. 1980 Aug 2;281(6236):386-7. 
276. Samkoff JS, Hockenberry S, Simon LJ, Jones RL. Mortality of young physicians in the United States, 1980-1988. Acad Med. 1995 Mar;70(3):242-4.

277. Sargent DA, Jensen VW, Petty TA, Raskin H. Preventing physician suicide. The role of family, colleagues, and organized medicine. JAMA. 1977 Jan 10;237(2):143-5.

278. Sargent DA. My Dear Colleague: Are You Considering Suicide. JAMA. 1986;255(19):2599.

279. Schernhammer ES, Colditz GA. Suicide rates among physicians: a quantitative and gender assessment (meta-analysis). Am J Psychiatry. 2004 Dec;161(12):2295-302.

280. Schernhammer E. Taking Their Own Lives — The High Rate of Physician Suicide. N Engl J Med. 2005;352(24):2473-6.

281. Schlicht SM, Gordon IR, Ball JR, Christie DG. Suicide and related deaths in Victorian doctors. Med J Aust. 1990 Nov 5;153(9):518-21.

282. Schultz SL, Russell AT. The emotionally disturbed child psychiatry trainee. J Am Acad Child Psychiatry. 1984 Mar;23(2):22632.

283. Schwenk TL, Davis L, Wimsatt L a. Depression, stigma, and suicidal ideation in medical students. JAMA. 2010 Sep 15;304(11):1181-90.

284. Seagroatt V, Rooney C. Suicide in doctors. BMJ. 1993 Aug 14;307(6901):447.

285. Selby JB. Physician suicide. W V Med J. 2008;104(4):40-1.

286. Shanafelt TD, Balch CM, Dyrbye L, Bechamps G, Russell T, Satele D, et al. Special Report: Suicidal Ideation Among American Surgeons. Arch Surg. 2011 Jan;146(1):54-62.

287. Shaw RS. Mental health and suicide. N Engl J Med. 1967;277(7):378-9.

288. Sheikhmoonesi F, Zarghami M. Prevention of physicians’ suicide. Iran J psychiatry Behav Sci. 2014;8(2):1-3.

289. Sher L. Towards a model of suicidal behavior among physicians. Rev Bras Psiquiatr. 2011 Jun;33(2):111-2.

290. Sher L, Braquehais MD. Suicidal behavior in military veterans and health care professionals. Aust N Z J Psychiatry. 2014;48(6):589.

291. Shortt SED. Psychiatric illness in physicians. Can Med Assoc J. 1979;121(3):283-8.

292. Simon H. Mortality Among Medical Students, 1947-1967. Vol. 43, Journal of Medical Education. 1968. p. 1175-82.

293. Simon W, Lumry GK. Suicide among physician-patients. J Nerv Ment Dis. 1968 Aug;147(2):105-12.

294. Singh D. NHS criticised over suicide of mentally ill doctor. BMJ. 2003 Nov 1;327(7422):1008-d-0.

295. Skegg K, Firth H, Gray A, Cox B. Suicide by occupation: Does access to means increase the risk? Aust N Z J Psychiatry. 2010;44(5):429-34.

296. Sobowale K, Zhou N, Fan J, Liu N, Sherer R. Depression and suicidal ideation in medical students in China: a call for wellness curricula. Int J Med Educ. 2014;5:31-6.

297. Sonneck G, Wagner R. Suicide and Burnout of Physicians. OMEGA - J Death Dying. 1996;33(3):255-63.

298. Spear SL. Physician suicide. Plast Reconstr Surg. 2001 Sep 15;108(4):1078-80.

299. Sponar J, Pivec L, Sormova Z. Suicide Among Doctors. Br Med J. 1964 Mar 28;1(5386):789-90.

300. Stack S. Suicide risk among physicians: A multivariate analysis. Arch Suicide Res. 2004;8(3):287-92.

301. Stallman HM, Wilson C. Could explicit teaching of coping planning in suicide prevention curricula improve resilience in medical students? Med Teach. 2017;39(7):680.

302. Stefansson CG, Wicks S. Health care occupations and suicide in Sweden 1961-1985. Soc Psychiatry Psychiatr Epidemiol. 1991;26(6):259-64.

303. Støen Grotmol K, Gude T, Moum T, Vaglum P, Tyssen R. Risk factors at medical school for later severe depression: A 15-year longitudinal, nationwide study (NORDOC). J Affect Disord. 2013;146(1):106-11.

304. Sun L, Zhou C, Xu L, Li S, Kong F, Chu J. Suicidal ideation, plans and attempts among medical college students in china: The effect of their parental characteristics. Psychiatry Res. 2017;247(April 2016):139-43.

305. Swanson SP, Roberts LJ, Chapman MD. Are anaesthetists prone to suicide? A review of rates and risk factors. Anaesth Intensive Care. 2003 Aug;31(4):434-45.

306. Sweet J. Fare Well. JAMA. 1991;265(12).

307. Talih F, Warakian R, Ajaltouni J, Shehab AAS, Tamim H. Correlates of Depression and Burnout Among Residents in a Lebanese Academic Medical Center: a Cross-Sectional Study. Acad Psychiatry. 2016 Feb 6;40(1):38-45. 
308. Talih F, Daher M, Daou D, Ajaltouni J. Examining Burnout, Depression, and Attitudes Regarding Drug Use Among Lebanese Medical Students During the 4 Years of Medical School. Acad Psychiatry. 2018 Apr 2;42(2):288-96.

309. Tan TS, Sidik SM, Rampal L, Ibrahim N. Prevalence and predictors of suicidality among medical students in a public university. Med J Malaysia. 2015;70(1):1-5.

310. Tateno M, Jovanović N, Beezhold J, Uehara-Aoyama K, Umene-Nakano W, Nakamae T, et al. Suicidal ideation and burnout among psychiatric trainees in Japan. Early Interv Psychiatry. 2017;(September 2016):17-9.

311. Thomas CB, Greenstreet RL. Psychobiological characteristics in youth as predictors of five disease states: suicide, mental illness, hypertension, coronary heart disease and tumor. Johns Hopkins Med J. 1973;132(1):16-43.

312. Thomas CB, Duszynski KR. Are words of the Rorschach predictors of disease and death? The case of "whirling." Psychosom Med. 1985;47(2):201-11.

313. Thomas JC. Re-Visioning Medicine. J Med Humanit. 2014;35(4):405-22.

314. Thompson D, Goebert D, Takeshita J. A Program for Reducing Depressive Symptoms and Suicidal Ideation in Medical Students. Acad Med. 2010 Oct;85(10):1635-9.

315. Tjia J, Givens JL, Shea JA. Factors associated with undertreatment of medical student depression. J Am Coll Heal. 2005;53(5):219-24.

316. Torre DM, Wang N-Y, Meoni LA, Young JH, Klag MJ, Ford DE. Suicide Compared to Other Causes of Mortality in Physicians. Suicide Life-Threatening Behav. 2005;35(2):146-53.

317. Tyssen R, Vaglum P, Grønvold NT, Ekeberg $\varnothing$. Suicidal ideation among medical students and young physicians: a nationwide and prospective study of prevalence and predictors. J Affect Disord. 2001;64(1):69-79.

318. Tyssen R, Hem E, Vaglum P, Grønvold NT, Ekeberg $\varnothing$. The process of suicidal planning among medical doctors: predictors in a longitudinal Norwegian sample. J Affect Disord. 2004 Jun;80(2-3):191-8.

319. Ullmann D, Phillipst RL, Beeson WL, Dewey HG, Brin BN, Kuzma JW, et al. Cause-Specific Mortality Among Physicians With Differing Life-styles. JAMA J Am Med Assoc. 1991;265(18):2352-9.

320. Valaske MJ. Suicide by Physicians on Probation. JAMA J Am Med Assoc. 1981 Jan 16;245(3):236.

321. Van Der Heijden F, Dillingh G, Bakker A, Prins J. Suicidal thoughts among medical residents with burnout. Arch Suicide Res. 2008;12(4):344-6.

322. van Niekerk L, Viljoen AJ, Rischbieter P, Scribante L. Subjective experience of depressed mood among medical students at the University of Pretoria. South African J Psychiatry. 2008;14(1):27-31.

323. Van Niekerk L, Scribante L, Raubenheimer PJ. Suicidal ideation and attempt among South African medical students. South African Med J (Suid-Afrikaanse Tydskr vir Geneeskd. 2012 May 8;102(6 Pt 2):372-3.

324. Verberne TJP. Suicide in doctors. J Epidemiol Community Health. 2002 Mar;56(3):237.

325. Victoroff VM. My Dear Colleague: Are You Considering Suicide. JAMA. 1986;255(19):2600-in reply.

326. Vogel L. Physician suicide still shrouded in secrecy. CMAJ. 2016;188(17-18):1213.

327. von Brauchitsch H. The physician's suicide revisited. J Nerv Ment Dis. 1976 Jan 8;162(1):40-5.

328. Wada K, Yoshikawa T, Goto T, Hirai A, Matsushima E, Nakashima Y, et al. Association of depression and suicidal ideation with unreasonable patient demands and complaints among Japanese physicians: A national cross-sectional survey. Int J Behav Med. 2011;18(4):384-90.

329. Wallin U, Runeson B. Attitudes towards suicide and suicidal patients among medical students. Eur Psychiatry. 2003 Nov;18(7):329-33.

330. Wang Y, Liu L, Xu H. Alarm bells ring: Suicide among Chinese physicians. Med (United States). 2017;96(32):96-8.

331. Ward S, Outram S. Medicine: In need of culture change. Intern Med J. 2016;46(1):112-6.

332. Waring EM. Psychiatric illness in physicians: a review. Compr Psychiatry. 2000;15(6):519-30.

333. Watterson DJ. Psychiatric illness in the medical profession: incidence in relation to sex and field of practice. Can Med Assoc J. 1976;115(4):311-7.

334. Weigand J. Physicians View Death and Suicide *. Suicide Life-Threatening Behav. 1972;2(3):163-7.

335. West CP, Dyrbye LN, Satele D V., Sloan JA, Shanafelt TD. Concurrent validity of single-item measures of emotional exhaustion and depersonalization in burnout assessment. J Gen Intern Med. 2012;27(11):1445-52.

336. Williams D, Tricomi G, Gupta J, Janise A. Efficacy of Burnout Interventions in the Medical Education Pipeline. Acad Psychiatry. 2015 Feb 18;39(1):47-54. 
337. Williams LS. Manitoba suicides force consideration of stresses facing medical residents. CMAJ. 1997 Jun 1;156(11):1599-602.

338. Withy K, Mapelli P, Perez J, Finberg A, Green J. Hawai'i Physician Workforce Assessment 2016: Improvement in Physician Numbers but Physician Suicides of Concern. Hawai'i J Med public Heal a J Asia Pacific Med Public Heal. 2017;76(3 Suppl 1):3-9.

339. Worley LLM. Our Fallen Peers: A Mandate for Change. Acad Psychiatry. 2008 Feb 1;32(1):8-12.

340. Yaghmour NA, Brigham TP, Richter T, Miller RS, Philibert I, Baldwin DC, et al. Causes of death of residents in ACGMEAccredited programs 2000 through 2014: Implications for the learning environment. Acad Med. 2017;92(7):976-83.

341. Yandoli AH. Stress and medical marriages. Stress Med. 1989;5(4):213-9.

342. Yasri S, Wiwanitkit V. Committing suicide by physicians: A summary from Thai situation. Ann Trop Med Public Heal. 2017;10(2):460-1.

343. Yoon JD, Arora VM. Is there a connection between high educational debt and suicidal ideation among medical students? Ann Intern Med. 2009 Feb 17;150(4):285; author reply 285.

344. Young JJ, Ursano RJ, Bally RE, McNeil DS. Consultation to a clinic following suicide. Am J Orthopsychiatry. 1989 Jul;59(3):4736.

345. Zheng A, Wang Z. Social and psychological factors of the suicidal tendencies of chinese medical students. Biopsychosoc Med. 2014;9(1):1-4.

346. Zisook S, Young I, Doran N, Downs N, Hadley A, Kirby B, et al. Suicidal Ideation among Students and Physicians at a U.S. Medical School: A Healer Education, Assessment and Referral (HEAR) Program Report. Omega - J Death Dying. 2016;74(1):35-61.

347. Zuk GH. Affective Disorder and Suicide in Women Physicians: Other Views. Am J Med. 1979;136(12):1605. 